\title{
Removal of microplastics from the environment. A review
}

\author{
Mohsen Padervand ${ }^{1,2} \cdot$ Eric Lichtfouse $^{3}$ (D) $\cdot$ Didier Robert $^{4} \cdot$ Chuanyi Wang $^{1}$ (i)
}

\begin{abstract}
The production of fossil fuel-derived, synthetic plastics is continually increasing, while poor plastic waste management has recently induced severe pollution issues. Microplastics are plastic particles smaller than $5 \mathrm{~mm}$. Microplastics are ubiquitous and slowly-degrading contaminants in waters and soils. Microplastics have long residence time, high stability, high potential of being fragmented and can adsorb other contaminants. Many aquatic species contain microplastics, which are in particular easily accumulated by planktonic and invertebrate organisms. Then, microplastics are transferred along food chains, leading to physical damages, decrease in nutritional diet value and exposure of the living organism to pathogens. Raw plastics contain chemical additives such as phthalates, bisphenol A and polybrominated diphenyl ethers that may induce toxic effects after ingestion by living organisms. Furthermore, the adsorption capability of microplastics makes them prone to carry several contaminants. Methods to remove microplastics from water and other media are actually needed. Here, we review microplastics occurrence, transport, raw polymers and additives, toxicity and methods of removal. Removal methods include physical sorption and filtration, biological removal and ingestion, and chemical treatments. Mechanisms, efficiency, advantages, and drawbacks of various removal methods are discussed.
\end{abstract}

Keywords Microplastic pollution $\cdot$ Environment $\cdot$ Removal method

\section{Introduction}

The global production of plastics has highly increased since 1950 to improve human life and reached almost 381 million tons in 2015 (Ritchie and Roser 2018). This increase has, however, induced global plastic pollution, making plastics

Mohsen Padervand

padervand@maragheh.ac.ir; mohsenpadervand@gmail.com

$\triangle$ Chuanyi Wang

wangchuanyi@sust.edu.cn

Eric Lichtfouse

eric.lichtfouse@gmail.com

Didier Robert

didier.robert@univ-lorraine.fr

1 School of Environmental Science and Engineering, Shaanxi University of Science and Technology, Xi' an 710021, China

2 Department of Chemistry, Faculty of Science, University of Maragheh, Maragheh, Iran

3 Aix-Marseille Univ, CNRS, IRD, INRAE, Coll France, CEREGE, 13100 Aix-en-Provence, France

4 ICPEES, Université de Lorraine, 12 rue Victor Demange, 57500 Saint-Avold, France pollutants of concern (MacArthur et al. 2016). Microplastics are plastics with size lower than $5 \mathrm{~mm}$, originating from the exfoliation and degradation of many types of plasticbased products released into ecosystems (Zhang et al. 2018). Microplastics has been reported in ocean sediments (Van Cauwenberghe et al. 2013), urban and rural areas (Hirai et al. 2011), freshwaters (Faure et al. 2015) and seawaters (Law et al. 2014). Most reports suggest an accumulation of microplastics in aquatic environments, and, as a consequence, a higher exposure of living organisms to microplastics and their degradation by-products (Andrady 2011; Sun et al. 2019).

Microplastics are categorized as primary microplastics, which are raw materials used in domestic and personal care products, and secondary microplastics arising from the degradation of raw plastic particles by physical, chemi$\mathrm{cal}$, and biological processes in the environment (Galgani et al. 2013). Long-term durability due to their polymeric structure and easy transport between different habitats make microplastics of high concern for biologists and environmentalists (Fig. 1). Major raw polymers include polyethylene terephthalate (PET), polyurethane (PU), polystyrene (PS), polyvinylchloride (PVC), polypropylene (PP), polyesters, 


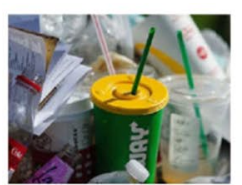

Large plastic items

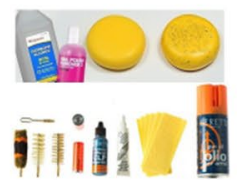

Cosmetic, cleaning,

other polmeric products

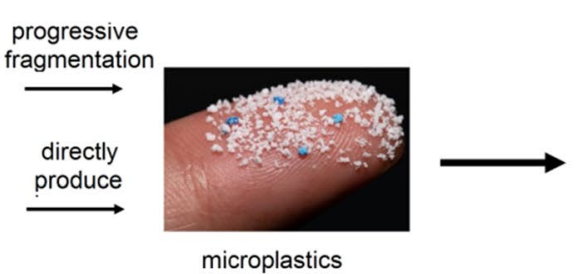

microplastics

Fig. 1 Microplastics sources, transformation and transport

polyethylene (PE) and polyamide (PA, nylon). Poor plastic waste management has resulted in ubiquitous microplastics occurrence (Gilani et al. 2019; Thompson 2015). Several reports show that long-term exposure to microplastics causes chronic toxicity, yet there is no evidence on their acute fatal effects (Li et al. 2018a; Sussarellu et al. 2016). Microplastic toxicity is controlled by different routes depending upon their chemical structure and additives used as linkage during polymerization (Meeker et al. 2009; Sussarellu et al. 2016). As an example, polystyrene microplastics are able to be transferred in blood, causing reproductive disruption in marine filter feeders (Law et al. 2014).

To our best knowledge, this is the first review on microplastics removal. We discuss microplastic additives, occurrence, transport and toxicity, then we review removal methods. Removal methods include sorption and filtration, removal based on chemical phenomena, and biological ingestion treatments. Advantages, disadvantages and efficiency of different methods are compared at the end.

\section{Microplastic sources, transport, polymers and additives}

\section{Microplastic sources and occurrence}

Microplastics can be found worldwide in coastal regions and aquatic ecosystems in various size fractions due to the transport phenomena including wind and ocean currents. Primary sources are household sewage discharge including polymeric particles from cosmetic and cleaning products, feedstocks used to manufacture plastic products, and plastic pellets or powders used for air blasting (Jiang 2018). Progressive fragmentation of larger plastic items under the atmospheric conditions, e.g., by mechanical degradation and UV light exposure, thus contributing to the entrance of considerable amounts of microplastics to

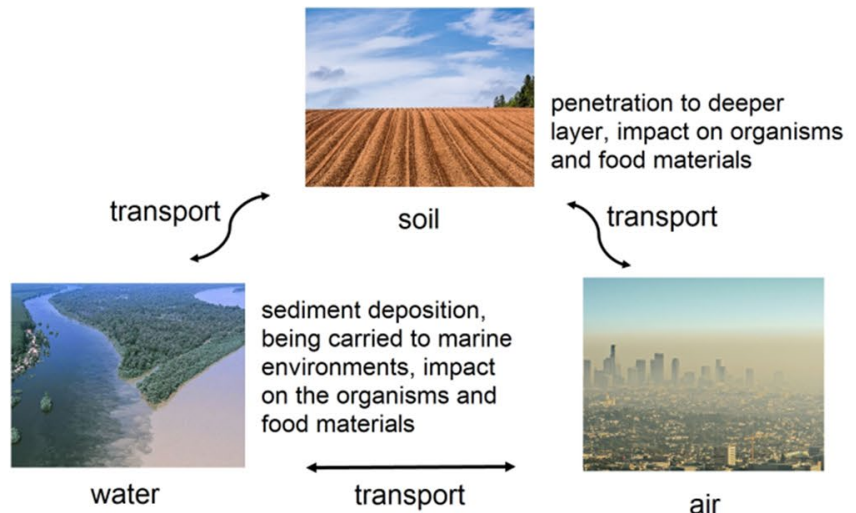

air

the environment, is the secondary source of microplastics (Eriksen et al. 2014). This increases plastic debris availability for being ingested by a large variety of organisms and highlights the appearance of further environmental hazards (Thompson et al. 2009).

Wastewater treatment plants are also a major source of microplastics release (Browne et al. 2011; Long et al. 2019). Whereas large plastic particles are efficiently removed during wastewater treatment, microplastics often bypass the treatment units, thus entering and accumulating in the aquatic environment (Murphy et al. 2016). Noteworthy, a large number of water treatment plants are located near the ocean and seawater, thus inducing a high microplastic release source. For instance, in mainland China, about 1873 wastewater plants $(56 \%)$, out of 3340 , with $78 \times 10^{6} \mathrm{~m}^{3} /$ day of treatment capacity, are located in coastal regions where their effluents can be directly or indirectly discharged into aquatic ecosystems (Jin et al. 2014). To address this issue, many researchers are investigating the fate, occurrence, detection and removal of microplastics in the water treatment plants (Beljanski 2016; Carr et al. 2016; Sun et al. 2019).

\section{Microplastic transport}

Sea and ocean are viewed as the major sinks for microplastics, whereas freshwaters and terrestrial environments are the main sources. Indeed, early research found that microplastic litter reaching oceans by rivers contains particles found in soils (Horton et al. 2017a). This implies that freshwaters and soils are also sinks of microplastics, as evidenced by high concentrations of microplastics in some terrestrial and freshwater areas (Nizzetto et al. 2016). The long-term durability of microplastic fibers found in deeper layers $(\sim 25 \mathrm{~cm})$ of agricultural soils treated by sewage sludge as fertilizer (Zubris and Richards 2005), suggests a gradual transport in solid media, then further 
accumulation at depth; thus making agricultural and forest soils more likely to retain microplastics compared to urban areas (Lwanga et al. 2017).

As rivers carry a huge volume of plastic particles over the large distances, microplastics probably settle out along with sinking sediments, particularly where flow energy drops, for instance in retard-moving riverbeds. Accordingly, futher sediment deposition of microplastics in lakes where water flow is the lowest and sedimentation rate is high, should induce high accumulation (Corcoran et al. 2015).

The shape diversity, small size, lightweight and low density of microplastics contribute to their widespread transport and facile dispersal across large distances on land and within aquatic systems by storm sewers, wind and other natural currents (Horton and Dixon 2018). Larger size and higher density result in facile sinking and sediment deposition of the microplastics (Horton et al. 2017b). Furthermore, irregularly shaped microplastics with jagged geometry and sharp ends are more likely retained underwater, rather than returning to the surface, whereas spherical particles show a higher tendency to stay at the surface (Ballent et al. 2012; Lagarde et al. 2016).

Microplastics transport pathways in the air are not fully understood (Horton and Dixon 2018). Noteworthy, in the air, there are few dispersal boundaries, compared to water systems. Nonetheless, microplastics transport within the atmosphere is not totally independent of aquatic and terrestrial pollutions, and here further investigations are needed to elucidate the mechanisms (Dris et al. 2016).

As another major concern, due to their hydrophobicity and high surface area/volume ratio, microplastics are highly susceptible to sorb and carry persistent organic pollutants such as polychlorinated biphenyls (PCB), dichlorodiphenyltrichloroethane (DDT) and polyaromatic polycyclic aromatic hydrocarbons (PAH), which can be subsequently transferred to coastal regions and be desorbed inside living organisms (Browne et al. 2013). Consequently, the concentration of organic pollutants in coastal areas is expected to increase several orders of magnitude as a result of pollutant transport by microplastics. Microplastic morphology and transport are thus major characteristics controlling the other waterborne pollutants (Cole et al. 2011).

\section{Microplastic raw polymers and additives}

Polymeric ingredients of primary microplastics mainly include polyethylene, polypropylene and polystyrene, depending upon the type of the products manufactured by the factory; while secondary microplastics are predominantly made of polyester, acrylic and polyamide, forming fibers in the environment (Jiang 2018). The microplastic number in the inland freshwaters of Wuhan in China ranged between $1660.0 \pm 639.1$ and $8925 \pm 1591$ numbers $/ \mathrm{m}^{3}$; here the major types were polyethylene terephthalate and polypropylene (Wang et al. 2017). Low-density polyethylene has been also identified as the dominant type of microplastics.

Microplastics contain a large variety of chemical additives such as bisphenol A, phthalates and polybrominated diphenyl ethers, which are used during raw plastic synthesis to improve plasticity (Besseling et al. 2014, Murphy 2001). These additives are endocrine disruptors, and thus may exhibit toxic effects upon release. The concentration of such plasticizers in plastic debris of remote and urban beaches is up to $35 \mathrm{ng} / \mathrm{g}$ in remote beaches and up to $700 \mathrm{ng} / \mathrm{g}$ in urban beaches for bisphenol A; between 0.1 and $400 \mathrm{ng} / \mathrm{g}$ in remote beaches and up to $9900 \mathrm{ng} / \mathrm{g}$ in urban beaches for polybrominated diphenyl ethers; and up to $3940 \mathrm{ng} / \mathrm{g}$ for phthalates (Hirai et al. 2011). These plastic additives have been detected in most microplastic polymers (Jiang 2018). Researchers also reported the leaching of bisphenol A and nonylphenol from silicone and polycarbonate microplastics (Fasano et al. 2012). Accumulation of such chemicals in human bodies through biological phenomena is also reported (Talsness et al. 2009). The most alarming exposure route to microplastics for human is food, where the adverse effects of the chemical additives and mechanism of entrance to the organs are still unexplored (Wright and Kelly 2017). Accordingly, many efforts must be devoted to finding efficient strategies to abate the presence of microplastics in the environment. While there have been published reports on characterizing sources, occurrence, fate, methods for detection, and environmental effects; to date, few research and review papers have discussed removal processes of microplastics from contaminated systems.

\section{Toxicity of microplastics}

\section{Toxicity from the chemical structure}

The potential toxicity of microplastics arises from unreacted monomers, oligomers and chemical additives leaked from the plastic in the long rub (Thompson et al. 2004). Monomers and oligomers are both able to migrate from food packaging materials (Piringer and Baner 2008). As the concentration of the residuals reaches specific limits, they can be potentially absorbed by human bodies via different pathways. For instance, the presence of polystyrene residuals in food materials is reported to cause serious health issues, while epoxy resins made of bisphenol A are absorbed by living tissues, then interfer with the rate of cell division (Lau and Wong 2000).

Chemical additives are used during polymers manufacturing for improving the products performance. Additives 
include functional additives such as plasticizers, heat stabilizers, flame retardants, antioxidants, colorants, e.g. soluble azo-colorants and pigments, fillers such as kaolin and clay, and reinforcements, e.g. carbon and glass fibers. These additives are another source of toxicity. For example, researchers found that the release level of some phthalates from baby bottles was in the range of $50-150 \mu \mathrm{g} / \mathrm{kg}$ of food content after the contact time of $120 \mathrm{~min}$ at $70{ }^{\circ} \mathrm{C}$ (Simoneau et al. 2012). The release level of bisphenol A from food packaging items was estimated to be in the range of 100-800 ng/L, while the values were in the range of $\mu \mathrm{g} / \mathrm{L}$ for some phthalates under the same conditions (Fasano et al. 2012). Most of these additives are not chemically bound to the bulk plastic structures, implying easier release.

Nobre et al. (2015) studied the toxicity of raw and beachstranded microplastics on the development of embryos of Lytechinus variegatus, simulating leaching of the chemical additives into the water column and interstitial water by assays of elutriate and pellet-water interface, respectively. They found that raw microplastics induced more toxicity, enhancing anomalous embryonic development by $58.1 \%$ and $66.5 \%$ for the former and latter evaluation method, respectively. Their results also implied that the leaching of chemical compounds strongly depends upon the media compartment in which microplastics accumulate, and upon the exposure pathway. Hahladakis et al. (2018) reviewed migration and release rate, fate, and potential toxicity effects of additives on organisms and environment. The release of volatile compounds, e.g., benzene, toluene, ethylbenzene, styrene and methylene chloride, from plastics can also contribute to chronic health effects (Andrady 2017; Huff et al. 2010; Wexler and Gad 1998).

\section{Toxicity from physical properties}

Microplastics exert damage through the effect of a relatively large surface area/volume ratio. They absorb hydrophobic pollution from water, then carry this pollution to other habitats (Setälä et al. 2014). A study of the effect of phenanthrene-loaded low-density polyethylene glycol microplastics on biomarker responses in juvenile African catfish revealed significant tissue changes in the liver and brain of the organism (Karami et al. 2016).

The ingestion of microplastics by biota is a common way to induce toxicological effects (Hämer et al. 2014). Polystyrene microplastics enhance the bioavailability of fluoranthene compounds to marine mussels (Mytilus spp.) after 7 days of exposure under controlled experimental conditions (Paul-Pont et al. 2016). These results mean that ther is a higher fluoranthene concentration in mussels exposed to fluoranthene-loaded microplastics than those exposed to pure fluoranthene. Highest levels of antioxidant markers and histopathological damages were also observed for the former case. They explained the mechanism by interactions between the cell wall components of the marine mussels, e.g. p-glycoprotein, involved in pollutant excretion, and the microplastics surface.

Zhang et al. (2017) investigated the adverse effects of microplastics on the photosynthesis of the marine microalgae Skeletonema costatum. They found that the maximum growth inhibition ratio reached up to $39.7 \%$ after $96 \mathrm{~h}$ of exposure to microplastics with average diameter of $1 \mu \mathrm{m}$. Their results show a drastic decrease in chlorophyll content (20\%) and photosynthetic efficiency (32\%) after exposure to high concentration of microplastic $(50 \mathrm{mg} / \mathrm{L})$, leading to negative effects on microalgae growth. According to the results of morphological studies and scanning electron microscopy (SEM), they proposed both adsorption and aggregation of microplastics on the outer surface of microalgae as the most probable mechanism of toxicity.

Size dependency of microplastics toxicity was also confirmed by Lu et al. (2016) who investigated the exposure effects of polystyrene microplastics to zebra fish. They stated that a 7-day exposure resulted in accumulating the microplastics with size of $5 \mu \mathrm{m}$ in liver, gill and gut, while those with size of $20 \mu \mathrm{m}$ were just found in fish gill and gut. Moreover, lipid accumulation and inflammation of liver, oxidative stress, and adverse alterations in the metabolism profile of the fish liver were the main toxicity outcomes.

The shape and texture of the ingested microplastics also influence their toxicity and absorption capability. According to $\mathrm{Au}$ et al. (2015), polypropylene microplastic fibers were more toxic than polyethylene microplastic spherical particles to the freshwater amphipod, Hyalella azteca. They attributed this to the longer residence time of the fibers in gut, which modifies the ability of food processing, thus leading to serious changes in sublethal endpoints.

\section{Toxicity from microorganisms carried by microplastics}

The potential of microplastics to carry pathogenic bacteria has been explored by Kirstein et al. (2016). They observed Vibrio parahaemolyticus bacterial strains on some polyethylene, polypropylene and polystyrene marine microplastic particles gathered from North Sea. They highlighted the need for further consideration of health impacts of microbial assemblages in microplastics. A 10-day exposure to five types of $\sim 70 \mu \mathrm{m}$ microplastics led to intestinal damage including splitting of enterocytes and cracking of villi in zebrafish Danio rerio and nematode C. elegans, as model organisms of freshwater (Lei et al. 2018). They also demonstrated that 2-day exposure of $5.0 \mathrm{mg} / \mathrm{m}^{2}$ of microplastics considerably reduced calcium levels and survival rates, and inhibited body length and reproduction of 
C. elegans. They suggested that oxidative stress and intestinal damages are the main toxicity effects of microplastics.

Prata (2018) reviewed the potential toxicity of airborne microplastics and adverse effects of their low environmental concentrations on human health. They discussed the diseases aroused from airborne microplastics and pathophysiological mechanisms of toxicity including dust overload, oxidative stress, translocation, and gene mutation. They proposed that exposure to low atmospheric concentrations can contribute to incidence of cardiovascular, respiratory, and interstitial lung diseases.

Overall, the toxicity of microplastics arises from raw chemical additives, adsorption and transport of pollutants and microbes, and release to life and the environment. Toxicity depends physically on size and shape of microplastics. Biota and humans are affected by toxic effects of microplastics via mechanisms including sorption and aggregation in different organs, ingestion, and exertion of physical damages and disturbing the life systems. Research is needed to clarify how microplastics induce tissue changes and pathological disorders.

\section{Removal of microplastics using sorption and filtration methods}

\section{Adsorption on green algae}

The presence of microplastics in aquatic environments is expected to be more critical than other pollutants due to several harmful effects and death of organisms, e.g. fishes, mammals, marine birds and reptiles, arising from their entanglement and bioaccumulation (Cole et al. 2011; Graham and Thompson 2009; Gregory 2009). Their persistence and low degradability call for removal methods. Microplastics are generally categorized as persistent materials but they degrade more of less depending upon their nature and chemical structure. Microplastics with half-life times lower than the values defined in terms of REACH criteria for persistency (Table 1) can be considered as degradable, and do not pose a threat to the environment (Verschoor 2015). Microplastics are prone to sorb a large variety of waterborne

Table 1 Persistency criteria for contaminants in different media according to the REACH Annex XIII (Verschoor 2015)

\begin{tabular}{ll}
\hline Compartment & Half-life (days) \\
\hline Marine water & $>60$ \\
Fresh or estuarine water & $>40$ \\
Marine sediment & $>180$ \\
Fresh or estuarine sediment & $>120$ \\
Soil & $>120$ \\
\hline
\end{tabular}

contaminants on the surface, carry them and desorb into the new habitats (Rios et al. 2007). Their large surface area/ volume ratio makes adsorption of other contaminants likely.

Sundbaek et al. (2018) studied the adherence behavior of fluorescent microplastic particles on the surface of an edible marine microalgae, seaweed, named Fucus vesiculosus. The diameter size of the polystyrene microplastics was $\sim 20 \mu \mathrm{m}$, while the plant cells of the sorbent contained very narrow microchannels to restrict the translocation of polystyrene microplastics into the tissues. The results revealed a high sorption of microplastics ( $94.5 \%)$, mainly near the cut surfaces of the seaweed, which is explained by the role of released alginate compounds from cell walls in the cut regions. Indeed, because of the gelatinous characteristics of this anionic polysaccharide substance, alginate is able to improve the adherence of polystyrene particles on the seaweed's surface (Martins et al. 2013). This paper and the other researches on microalgae capabilities to sorb tiny plastic particles accentuate the effective role of microplastics' surface charge and microalgae's surface characters (Bhattacharya et al. 2010; Nolte et al. 2017). Investigating the adsorption of 20-500 nm polystyrene particles onto unicellular green algae, Pseudokirchneriella subcapitata, Nolte et al. (2017) concluded that positively charged polystyrene microplastics are more efficiently adsorbed on the algae's surface than those with negative charge.

Overall, the sorption of microplastics on algae surface strongly depends on particles' surface charge. Positively charged microplastics have higher tendency to be sorbed more efficiently, which is explained by the presence of an anionic polysaccharide in the algal chemical structure.

\section{Removal using membrane technology}

Li et al. (2018b) reported the use of dynamic membranes for the efficient removal of microplastics from a synthetic wastewater (Fig. 2). They investigated the effect of influent flux and particles concentration on the removal efficiency of dynamic membranes formed on a diatomite platform with $90 \mu \mathrm{m}$ of supporting mesh during filtration of the synthetic wastewater. Excellent filtration of microplastices was obtained in 20 min by decreasing the turbidity from 195 NTU for the influent to less than 1 for the effluent (Ersahin et al. 2017; Horton and Dixon 2018). Dynamic membrane formation is facilitated at higher influent fluxes and microplastics concentrations.

Ward (2015) designed an efficient microplastic removal tool based on polymer coatings as an elongated mesh screen. He claimed that the tool has good durability and has the advantage of being easily fabricated from commodious materials. Other tool advantages included the absence of electrical power and mechanical devices. 

experimental setup and graph ity with time when microplastics are removed (Li et al. 2018b). TMP transmembrane pressure, $N T U$ nephelometric turbidity unit
Fig. 2 Dynamic membrane showing the decrease in turbid-

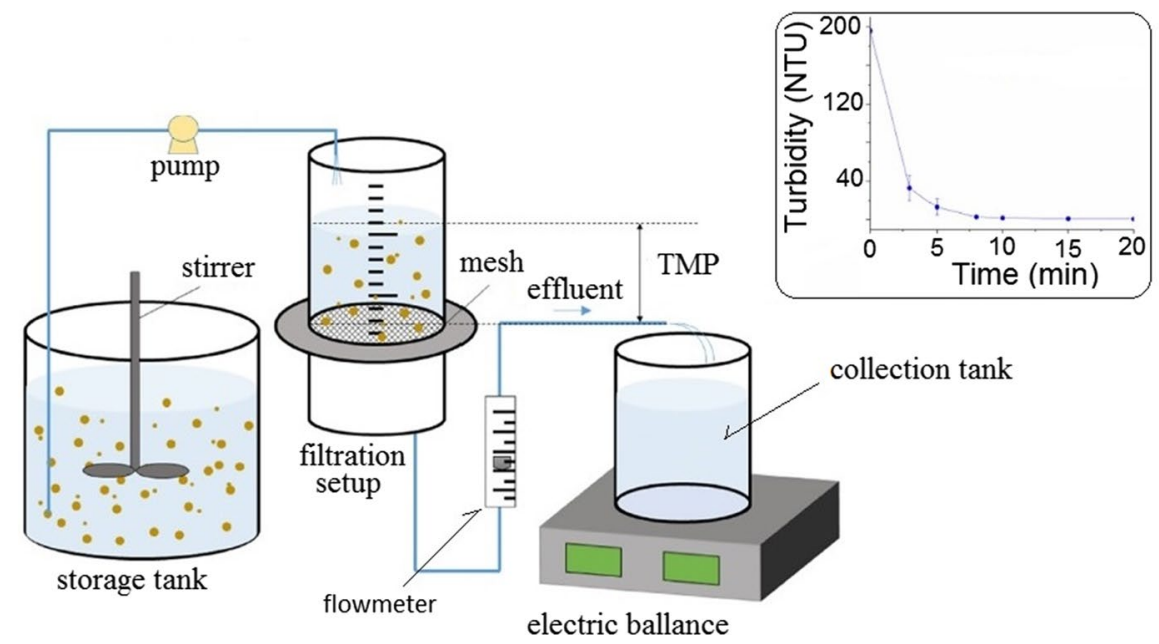

Membrane bioreactors, however, exhibit higher capacitie than simple dynamic membranes for the removal of microsized plastics (Lares et al. 2018; Talvitie et al. 2017a). Knoblock et al. (1994) studied the purification capability of a coupled system, taking advantage of porous membranes in combination with biological processes. Successful removal of a large variety of complex industrial wastewaters by membrane bioreactors confirms the suitability of this technology for the treatment for high-strength contaminants such as polymeric debris and microplastics (Gurung et al. 2016). Talvitie et al. (2017a) investigated the removal of various types of microplastics from wastewater treatment plant effluents using advanced final-stage treatment technologies including membrane bioreactor, disk filter, rapid sand filtration, and dissolved air floating (Fig. 3). They concluded that the membrane bioreactor eliminated $99.9 \%$, from 6.9 to 0.005 microplactic particle per L (Table 2). They also showed that membrane bioreactor, rapid sand filtration and dissolved air floating removed microplastics of any size, even the smallest size fractions of 20-100 $\mu \mathrm{m}$. Moreover, the removal efficiency did not depend upon the microplastics shape; particularly, textile fibers which were predominant in both influents and effluents during the treatment, were efficiently removed. Analysis of the samples by Fourier transform infrared spectroscopy (FTIR) indicated that the membrane bioreactor highly decreased the number of polymers in the final effluent, too, which highlights the good sorption capacity of the setup to trap microplastics of various chemical structures.

Membrane technologies were successfully used to remove microplastics from polluted aquatic environments. The removal efficiency over the membranes particularly depends on its durability, influent flux, size, and concentration of the microplastics. The combination of porous membranes with biological processes could enhance the removal efficiency up to $99.9 \%$.

\section{Removal using advanced filtration technologies in wastewater treatment plants}

Lares et al. (2018) recently studied the performance of a municipal wastewater treatment plant operating based on a pilot-scale, combined membrane bioreactor-conventional activated sludge methodology for the removal of microplastics. Their study took 3 months and sampling campaigns were every 2 weeks. The wastewater samples were collected from a municipal water treatment plant located next to the city center of Mikkeli in Finland. Including an aeration tank, for mixing the wastewater with air to activate microorganisms, and a sedimentation tank, where the sludge is separated from the treated wastewater, for the biological degradation and secondary purification, respectively, a conventional activated sludge system is also expected to improve the activity (Gurung et al. 2016). Results revealed a better removal of microplastics (99.4\%) using a membrane bioreactor compared to the conventional activated sludge treatment system (98.3\%). Microplastics concentration in the final effluent of the former system was estimated to be $0.4 \pm 0.1 \mathrm{MP} / \mathrm{L}$, which was lower in comparison with that evaluated for the later process $(1.0 \pm 0.4 \mathrm{MP} / \mathrm{L})$. They also stated that the main reason for observing a narrow range of final microplastics concentrations is probably due to opting for different processing steps and wastewater samples than previous works (Leslie et al. 2017; Mintenig et al. 2017; Murphy et al. 2016).

11 wastewater treatment plants in Changzhou, China, were studied for their efficiency to remove microplastics by following the abundance, color, shape and dimensional changes during the removal steps (Ma et al. 2019). All plants that used several treatment steps such as subsequent tanks for floating and sedimentation, and filtration processes, eliminated more than $90 \%$ of microplastics from the influents, with a final removal efficiency reaching $97.15 \%$. The most important reasons that cause variation in removal efficiencies 
Fig. 3 Microplastics removal efficiency, in terms of number of microplastics per liter, MP/L, after treatment by final-stage treatment technologies (Talvitie et al. 2017a)
Table 2 Average microplastic concentrations before and after treatment with different technologies

\section{microplastic concentration before and after treatments}
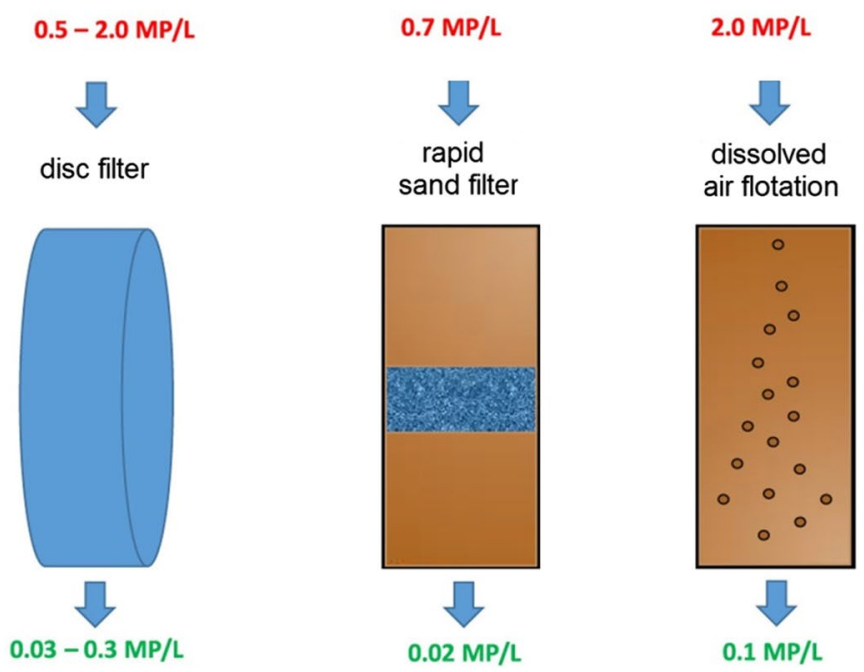

$6.9 \mathrm{MP} / \mathrm{L}$

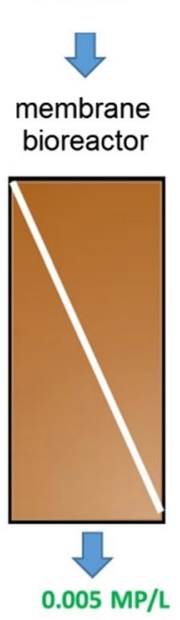

\begin{tabular}{|c|c|c|c|c|}
\hline Treatment & Effluent type & Before (MP/L) & After (MP/L) & Removal (\%) \\
\hline Disk filter $10^{\mathrm{a}}$ & Secondary & 0.5 & 0.3 & 40.0 \\
\hline Disk filter $20^{\mathrm{a}}$ & Secondary & 2.0 & 0.03 & 98.5 \\
\hline Rapid sand filter & Secondary & 0.7 & 0.02 & 97.1 \\
\hline Dissolved air flotation & Secondary & 2.0 & 0.1 & 95.0 \\
\hline Membrane bioreactor & Primary & 6.9 & 0.005 & 99.9 \\
\hline
\end{tabular}

Data are given in number of microplastics per liter of effluent

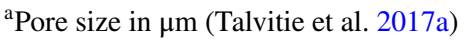

might be daily processing volume, different raw water and type of treatment processes. Large-size microplastics were less abundant in the effluents, in agreement with previous reports (Horton and Dixon 2018). In addition, fiber rayon and polyethylene terephthalate were the main ingredients of these microplastics, and reached the highest removals.

The microplastics removal methodology used by municipal sewage treatment plants was studied by researchers in Beijing, China (Yang et al. 2019). The influents were initially treated by a series of processes including aerated grit chamber, primary and secondary sedimentation tanks following $\mathrm{A}^{2} \mathrm{O}$ treatments, e.g., anaerobic, anoxic and aerobic. Finally, advanced treatment processes including denitrification, ultrafiltration, ozonation and ultraviolet are applied to complete the cycle and remove microplastics from wastewater. The results of FTIR analysis revealed the presence of 18 polymers in the effluent, in which polyethylene terephthalate and polyester had the highest abundances of 42.26 and $19.1 \%$, respectively. $58.84 \%$ of the microplastics population in influents was removed during the primary step of aerated grit treatment, while the removal efficiency reached to $71.67 \%$ following the advance treatment processes. Although the overall removal efficiency in the present sewage treatment plant, of $95.16 \%$, was outstandingly less than that of for membrane bioreactors, of $99.9 \%$, it was comparable to the efficiency of dissolved air flotation technologies and sand filters (Talvitie et al. 2017b). Noteworthy, the treatment processes currently employed at sewage treatment plants are not necessarily designed for the removal of microplastics. Regardless, these processes are able to eliminate a large portion of microplastics from the wastewater. The researchers finally estimated that sewage treatment plants release almost $0.59 \times 10^{9}$ items of microplastic into the aquatic ecosystems.

Overall, sorption and filtration methodologies show a good efficiency for the treatment for microplastics-containing wastewater, mainly in combination with other procedures such as biological and sedimentation processes. To achieve higher removal efficiency, membrane bioreactors are simultaneously used with other advanced physical-chemical 
treatments in most wastewater treatment plants all over the world, but it has still been confirmed that these plants act as microplastics sources to aquatic environment.

\section{Chemical methods to treat microplastics}

Many wastewater treatment plants worldwide use coagulation and agglomeration processes to form enlarged contaminant particles that are easier to separate (Hu et al. 2012; Lee et al. 2012; Shirasaki et al. 2016). These processes involve $\mathrm{Fe}$ - and Al-based salts and other coagulants to bind tiny particles via uptake-complexation mechanisms initiated by a ligand exchange, thus forming strong bonds between waste particles (Chorghe et al. 2017).

Ariza-Tarazona et al. (2019) recently studied the removal of polyethylene microplastics using iron and aluminum salt coagulants and ultrafiltration (Fig. 4). The experiments were carried out under different concentrations of $\mathrm{Al}^{3+}$ and $\mathrm{Fe}^{3+}$ ions, and the results indicated that $\mathrm{Al}^{3+}$ has better performance than $\mathrm{Fe}^{3+}$. Also, the microplastic removal efficiency was scarcely modified by the $\mathrm{pH}$ of the solution at low concentration of Al coagulant source, $0.5 \mathrm{mM}$, whereas removal efficiency decreased by increasing the $\mathrm{pH}$, particularly for small-sized microplastics, of diameter lower than $0.5 \mathrm{~mm}$. They found that polyacrylamide (PAM), an enhancing coagulation agent, increased the removal efficiency for small microplastics much better than for large particles under high $\mathrm{Al}$ dosage of $5 \mathrm{mM}$. This highlights the greater growth rate of small microplastics in the presence of cationic polyacrylamide. The growth rate was highly enhanced when anionic polyacrylamide was used for the removal efficiency for the smaller microplastics $(d<0.5 \mathrm{~mm})$ : here the removal was raised from $25.83 \%$ without polyacrylamide to $61.19 \%$ with $15 \mathrm{mg} / \mathrm{L}$ polyacrylamide, while it just increased from $4.27 \%$ to $18.34 \%$ for larger microplastics, of 2-5 $\mathrm{mm}$ diameter.

Ariza-Tarazona et al. (2019) also explored the removal of the microplastics with the same method but using $\mathrm{FeCl}_{3} \cdot 6 \mathrm{H}_{2} \mathrm{O}$ coagulation agent (Fig. 5). They found that the

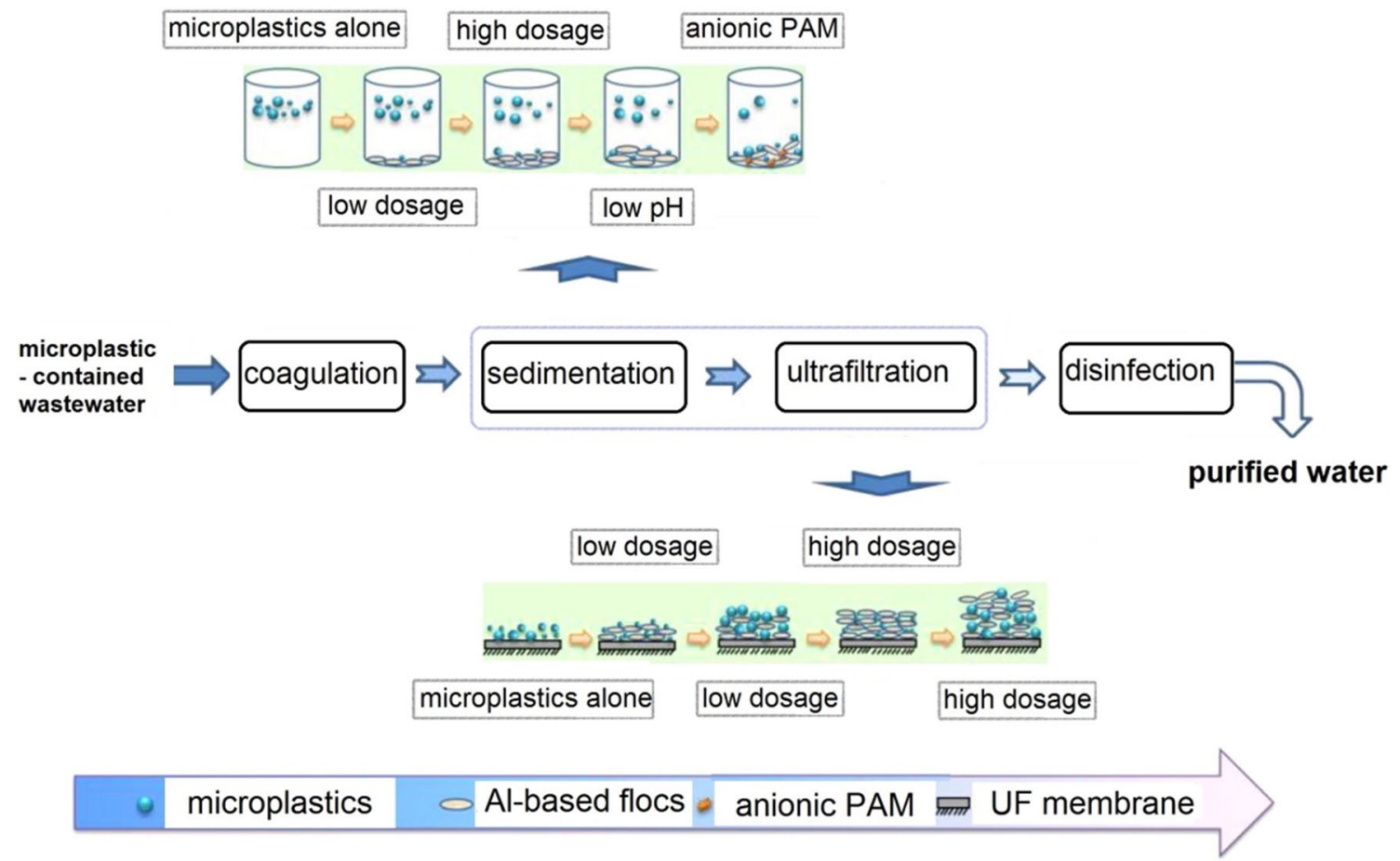

Fig. 4 Microplastic removal by coagulation, sedimentation and ultrafiltration (UF) (Ma et al. 2019). The effect of anionic polyacrylamide (PAM), $\mathrm{pH}$ and the formation of Al-based flocs on the removal efficiency is well represented 

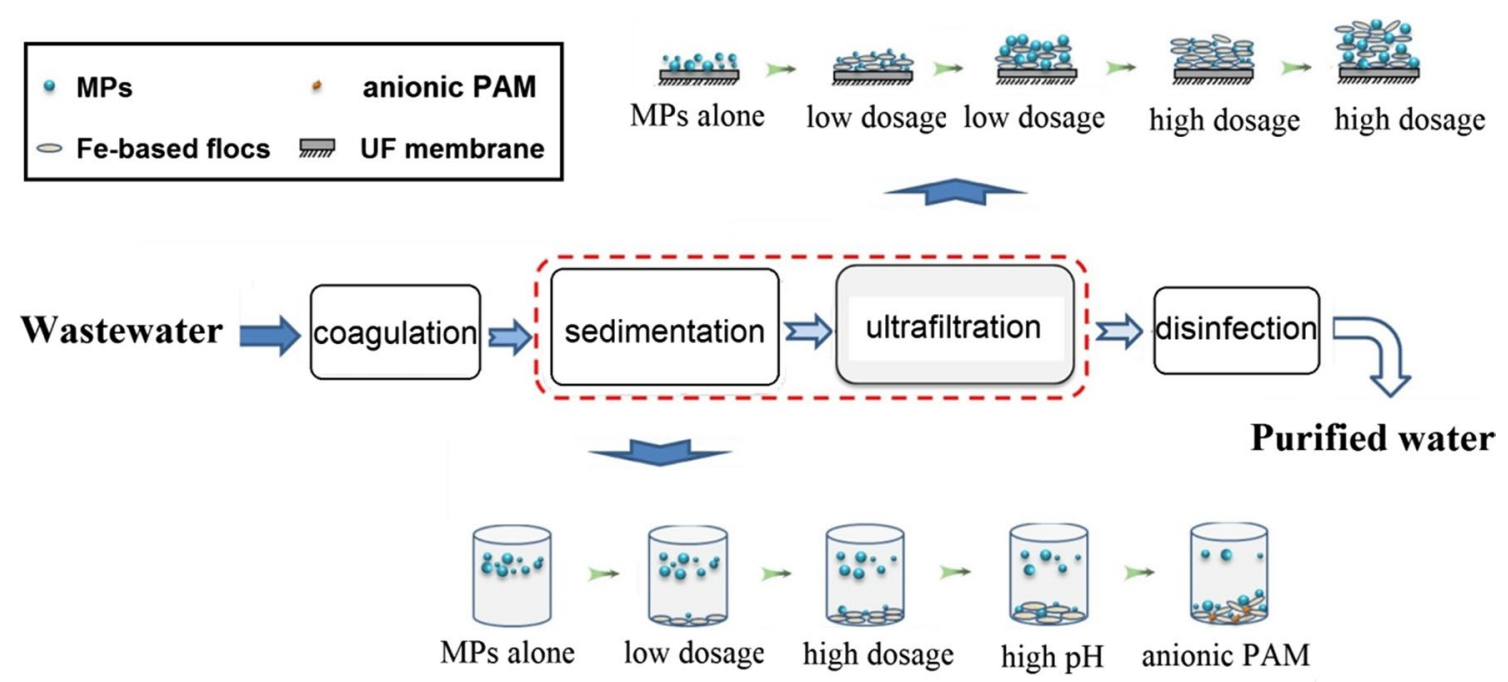

Fig. 5 Removal of polyethylene microplastics from the wastewater using $\mathrm{Fe}^{3+}$ coagulation, sedimentation and ultrafiltration processes (Ma et al. 2019). The effect of polyacrylamide (PAM), pH and the formation of Fe-based flocs on the removal efficiency is well represented. MPs microplastics, $U F$ ultrafiltration

$\mathrm{M}_{(\mathrm{aq})}^{n+}+n \mathrm{OH}^{-} \rightarrow \mathrm{MOH}_{n(\mathrm{~s})}$

The produced coagulants break up the colloids and stabilize the suspended microparticles surface charges, which allows the particles to get close to each other sufficiently for making interactions via van der Waals forces (Akbal and Camc1 2011). The coagulants simultaneously form a sludge blanket to trap the suspended microplastics in the wastewater sample. The results show a removal efficiency higher than $90 \%$ for all experiments using proposing electrocoagulation. The highest removal efficiency, 99.24\%, was obtained with $\mathrm{pH}$ of 7.5 and $\mathrm{NaCl}$ concentration of $0-2 \mathrm{~g} / \mathrm{L}$. Furthermore, the lowest tested current density of $11 \mathrm{~A} / \mathrm{m}^{2}$, which is the best in view of energy consumption, was the most efficient for achieving the highest removal rate.

Herbort et al. (2018) suggested agglomeration based on alkoxy-silyl bond formation via sol-gel reactions as a new sustainable removal approach for treatment for the microplastics originating from inert products of the textile and cosmetic industries. Functionalized molecular precursors were initially synthesized in an inert atmosphere, then used for bio-inspired alkoxy-silyl formation. Meanwhile, microplastics adhered together to form large three-dimensional agglomerates which can, afterward, be removed using costefficient filtration methods (Fig. 7). The sol-gel formed in this way is similar to hybrid organic-inorganic silica gels with a large variety of benefits and usages in sensors and optical materials, medicine, and corrosion protection (Nicole et al. 2004).

The mechanisms of degradation of microplastics are not fully known. Brandon et al. (2016) studied the degradative changes of the chemical structure of two types of microplastics including polypropylene and polyethylene
$2 \mathrm{H}_{2} \mathrm{O}_{(\mathrm{l})}+2 \mathrm{e}^{-} \rightarrow H_{2(\mathrm{~g})}+2 \mathrm{OH}^{-}$ 


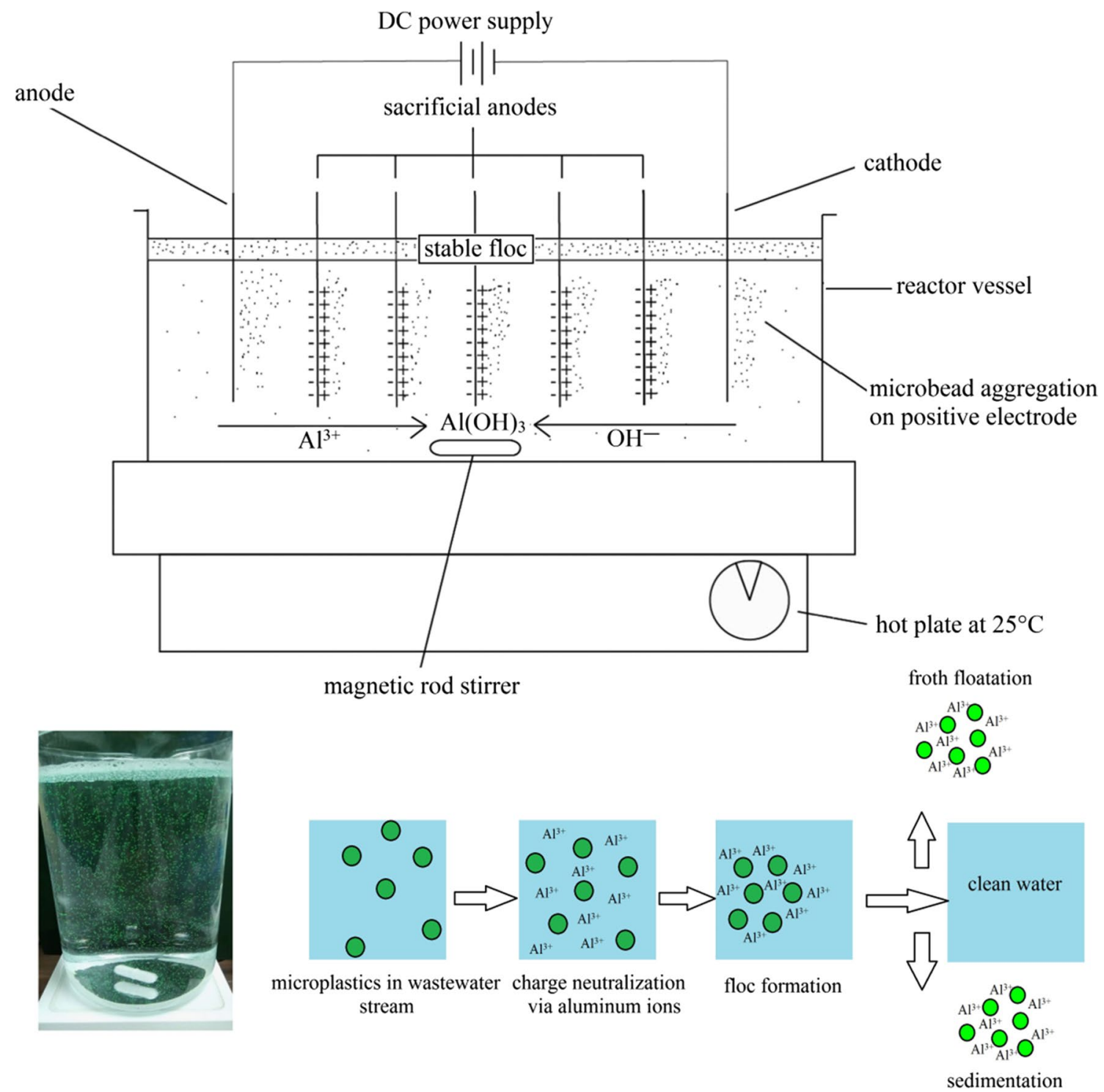

Fig. 6 Bench-scale reactor setup for the removal of microplastics using electrocoagulation method in which $\mathrm{Al}^{3+}$ acts as coagulation agent (Perren et al. 2018)

for 3 years under simulated realistic weather conditions. According to FTIR analysis, they found some slight nonlinear changes with time in moieties like carbonyl, hydroxyl and carbon-oxygen bonds, implying microplastics slow degradation.

The exposure of macroplastics to elements (Colom et al. 2003; Gulmine et al. 2003), microorganisms (Pathak 2017), catalysts (Hazrat et al. 2015), and photo-active materials ( $\mathrm{Li}$ et al. 2010) has been widely reported but there are no large number of publications on microplastics degradation. Liu et al. (2019) studied the long-term aging behavior of polystyrene and polyethylene microplastics treated by a combined heat-activated persulfate and Fenton method in the aquatic environment. According to their results, $\mathrm{O} / \mathrm{C}$ ratio and the average size of the microplastics play a role in the adsorption capacity and surface properties, which affect the microplastic oxidation rate significantly. Degradation of polyethylene microplastics in artificial seawater under dark and UV radiation to evaluate the structural and morphological alterations has been recently reported (Da Costa et al. 2018; Pathak 2017). FTIR analysis of the initial materials and products (Fig. 8) evidenced the stronger degradative role of the artificial seawater compared to UV illumination. This was confirmed by an increase of the organic content of the medium. As a control experiment, the researchers exposed microplastics to UV light alone for the same period of time and did not observe significant changes in the chemical structure, thus showing implying that salt is needed to 

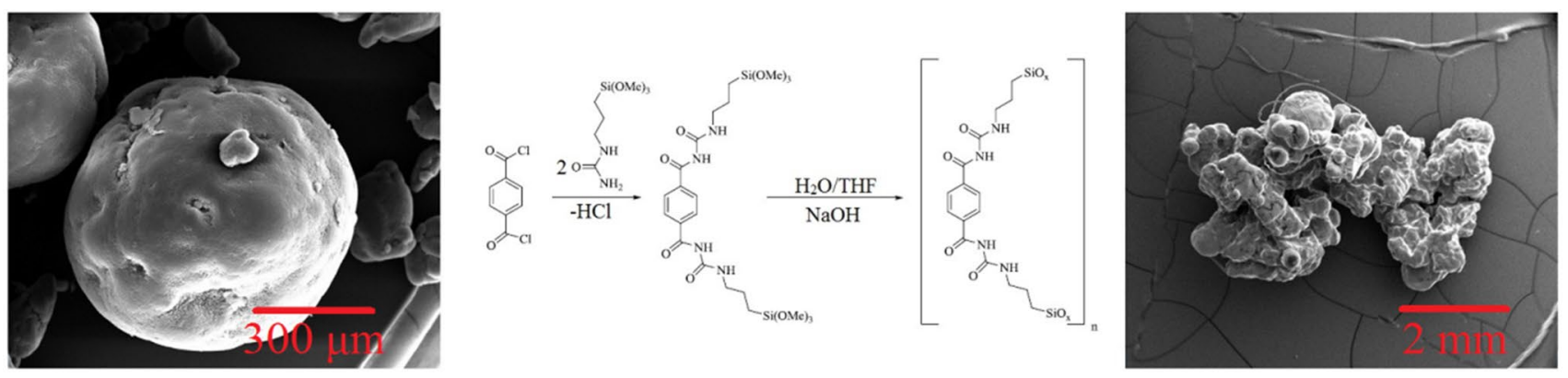

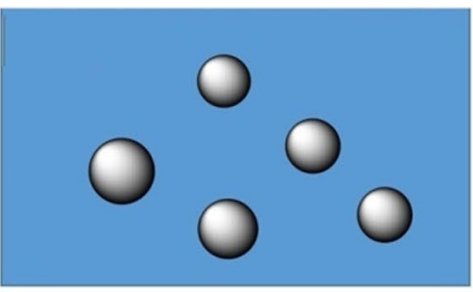

Microplastic Particles in Aquatic Medium

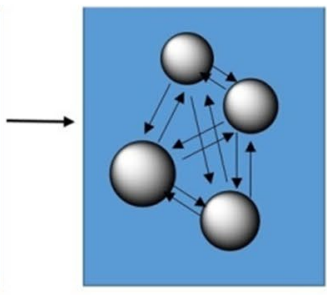

Localization of Microplastic Particles

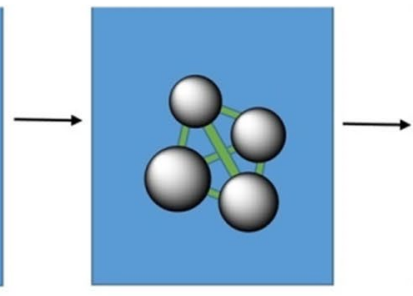

Water induced SolGel-Process

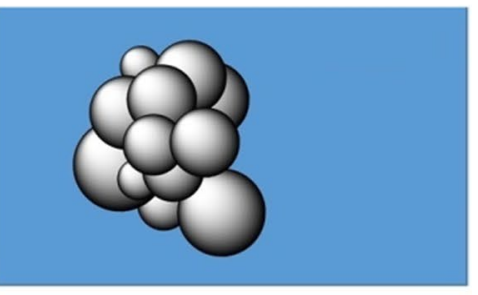

Agglomeration Product

synthesis reaction in the middle exhibits the formation process of the coagulation agent (Nicole et al. 2004)

Roval of polyethylene microplastics using alkoxy-silylinduced agglomeration. The microscopy images of the microplastic before agglomeration (above left) and after that (above right). The

Fig. 8 Fourier transform infraylene microplastics before and after an 8-week treatment with artificial seawater (Da Costa et al. 2018). The appearance of new bands assigned to the oxidized groups in the spectrum of the treated sample confirms the microplastic transformation red (FTIR) spectra of polyeth-

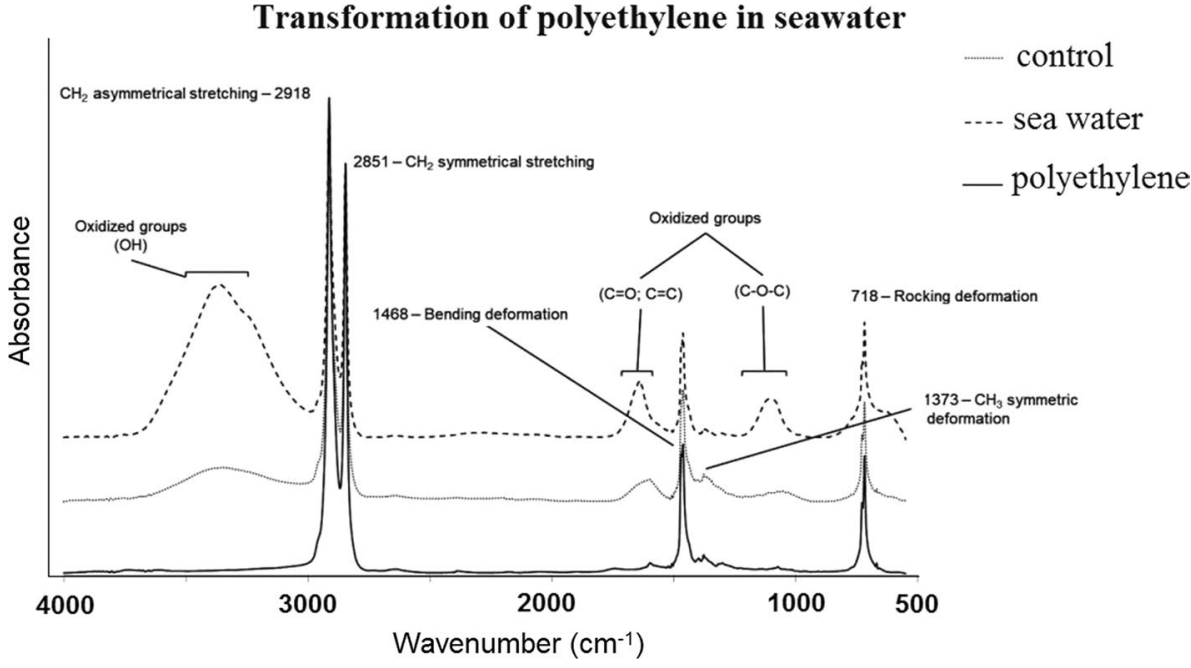

form oxidized sites. SEM images also revealed the effect of salt on microplastic surface morphology, in which observable crack lines were clearly detected. This strengthens the fact that media salinity facilitates microplastic degradation (Vasile and Pascu 2005).

Photocatalytic degradation of the organic contaminants is a destructive process triggered by absorbed photons on the surface of a semiconducting material for generating hyperactive radicals. Depending upon the semiconductor band gap, the energy of the incident photons and, subsequently, the suitable light source must be chosen. Photooxidation degradation, that is oxidation in the presence of light source and air, is the mostly common process for the breaking of polymeric chains (Yousif and Haddad 2013). Different mechanisms were suggested for the photochemical processes in the aqueous phase, in which hydroxyl radicals strongly promote the degradation reactions ( $\mathrm{Li}$ et al. 2010). Heterogeneous photocatalytic degradation of low-density polyethylene microplastics has been recently investigated in the aquatic media over the rod-like $\mathrm{ZnO}$ nanoparticles (Tofa et al. 2019). From the optical images, morphological changes including the appearance of wrinkles, brittleness, cracks and spots on photo-exposed surfaces of the microplastics were observed (Fig. 9). Also, the results revealed variations in elasticity 
properties of the sample exposed to photocatalytic conditions in comparison with nonirradiated wastewater, and this directly is in correlation to the changes in the strength of chemical bonds. Accordingly, the nanorods surface area influenced the stiffness degree of the microplastics and the photocatalytic performance. Liang et al. (2013) obtained FTIR data which confirmed the presence of newly formed functional groups such as carbonyl and vinyl during the photocatalytic treatment, they proposed a mechanism for the mineralization of microplastics in wastewater (Eqs. 6-13):

$$
\begin{aligned}
& \left(-\mathrm{CH}_{2}-\mathrm{CH}_{2}-\right)_{n}+\mathrm{OH} \rightarrow\left(-\mathrm{CH}_{2}-\mathrm{CH}-\right)_{n}+\mathrm{H}_{2} \mathrm{O} \\
& \left(-\mathrm{CH}_{2}-\mathrm{CH}^{-}-\right)_{n}+\mathrm{O}_{2} \rightarrow\left(-\mathrm{CH}_{2}-\mathrm{HCOO}^{-}-\mathrm{CH}_{2}-\right)_{n}
\end{aligned}
$$

$$
\begin{aligned}
& \left(-\mathrm{CH}_{2}-\mathrm{HCOO}-\mathrm{CH}_{2}-\right)_{n}+\left(-\mathrm{CH}_{2}-\mathrm{CH}_{2}-\right)_{n} \\
& \quad \rightarrow\left(-\mathrm{CH}_{2}-\mathrm{HCOOH}-\mathrm{CH}_{2}-\right)_{n}+\left(-\mathrm{CH}_{2}-\mathrm{CH}-\right)_{n}
\end{aligned}
$$

$\left(-\mathrm{CH}_{2}-\mathrm{HCOOH}-\mathrm{CH}_{2}-\right)_{n} \rightarrow\left(-\mathrm{CH}_{2}-\mathrm{HCO}-\mathrm{CH}_{2}-\right)_{n}+\mathrm{OH}$

$\left(-\mathrm{CH}_{2}-\mathrm{HCO}-\mathrm{CH}_{2}-\right)_{n} \rightarrow$ carbonyl groups (norrish type I)

$\left(-\mathrm{CH}_{2}-\mathrm{CO}-\mathrm{CH}_{2}-\right) \rightarrow\left(-\mathrm{CH}_{2}-\mathrm{CO}^{\circ}\right)_{n}$ $+\left(\mathrm{CH}_{2}-\mathrm{CH}_{2}-\right)_{n}($ norrish type II)

$$
\left(-\mathrm{CH}_{2}-\mathrm{CO}-\mathrm{CH}_{2}-\right) \rightarrow\left(-\mathrm{CH}_{2}-\mathrm{CO}\right)_{n}+\left(\mathrm{CH}_{2}=\mathrm{CH}_{2}\right)_{n}
$$

$\left(-\mathrm{CH}_{2}-\mathrm{HCO}\right)+\left(-\mathrm{CH}_{2}-\mathrm{COOH}\right)$

$$
+\left(-\mathrm{CH}_{2}-\mathrm{CO}-\mathrm{CH}_{2}-\right) \rightarrow \mathrm{CO}_{2}+\mathrm{H}_{2} \mathrm{O}
$$

Fig. 9 Decrease of the elasticity of microplastics after photocatalytic treatment with: A: $\mathrm{ZnO}$ (10 mM, 5 h), B: ZnO (3 mM, $5 \mathrm{~h})$ and $\mathrm{C}$ : control. Optical images of the treated microplastics, i photo-irradiated, only, for $175 \mathrm{~h}$, ii photo-irradiated in the presence of the $\mathrm{ZnO}$ nanorods, $3 \mathrm{mM}$ for $5 \mathrm{~h}$, iii photoirradiated in the presence of the $\mathrm{ZnO}$ nanorods, $10 \mathrm{mM}$ for $5 \mathrm{~h}$, iv photo-irradiated in the presence of the $\mathrm{ZnO}$ nanorods, $20 \mathrm{mM}$ for $5 \mathrm{~h}$, representing the development of holes, cracks, and spots (Tofa et al. 2019)
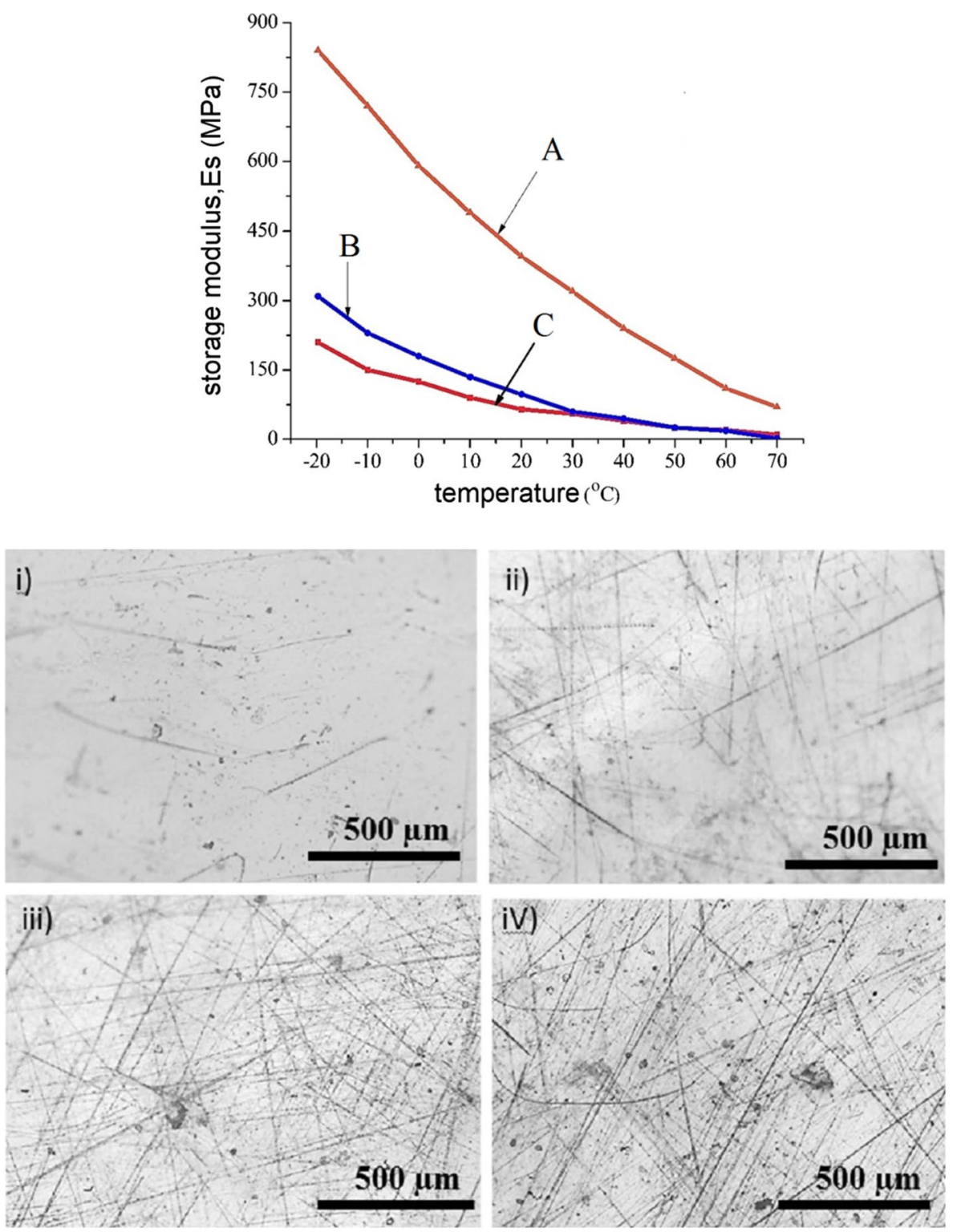
The design and degradative capability of the $\mathrm{TiO}_{2}$-based micro- and nanodevices for the photocatalytic treatment for microplastics have been studied (Sekino et al. 2012). Holding high potential for water purification, remediation of environmental pollutions and medicinal usages, photo-active micromotors have attracted huge attention (Eskandarloo et al. 2017; Zhang et al. 2018). Wang et al. (2019) reported the use of a Au-decorated $\mathrm{TiO}_{2}$-based micromotor for the efficient photocatalytic removal of polystyrene microplastics from wastewater under UV illumination (Fig. 10). The micromotor propulsion is supplied by photochemical reactions in water and hydrogen peroxide initiated by electron-hole generation processes. Although the lack of selectivity was the most important disadvantage of this system. The need for low concentrations of $\mathrm{H}_{2} \mathrm{O}_{2}$ for promoting the phoretic interactions, which enable the micromotor to move, makes this system actually non applicable in real wastewater.

Recently, Ariza-Tarazona et al. (2019) reported the ability of a protein-based $\mathrm{N}-\mathrm{TiO}_{2}$ photocatalyst to degrade the polyethylene microplastics in solid and aqueous phases. According to their results, photocatalytic treatment for the pollution resulted in $1.1 \%$ of the mass loss in the solid phase with the rate constant of $12.2 \times 10^{-4} / \mathrm{h}$ after $20 \mathrm{~h}$ of treatment time. These values were reported to be $6.4 \%$ and $38.2 \times 10^{-4} / \mathrm{h}$ in the aqueous phase. They demonstrated that surface area of the semiconductor and interactions between the photocatalyst surface and microplastics significantly influenced the removal efficiency. The SEM images and FTIR spectra have also provided good evidences to confirm the structural changes during the mineralization process.

To conclude, coagulation and agglomeration methods have been investigated to remove microplastics in the laboratory. The efficiency depends on the type of coagulant, $\mathrm{pH}$, the chemical composition of the media and the concentrations. Although salinity of the media and the presence of illumination source are reported to affect modify the degradation of microplastic structures in the aquatic environment, degradative processes have been rarely studied. Of special interest are photocatalytic nanomaterials which make use of both irradiation and catalytic degradation.

\section{Biological removal and ingestion}

\section{Microplastic removal by marine organisms}

Harrison et al. (2011) published "Interactions Between Microorganisms and Marine Microplastics: A Call for Research" to highlight the outstanding potential of microorganisms, including picoeukaryotes, bacteria and archaea, to facilitate the biological degradation of microplastics in coastal sediments. They discuss the interactions between synthetic microplastics and marine microorganisms. Many reports present the biological degradation of natural and

Fig. 10 Photocatalytic removal of polystyrene microplastics in water by a $\mathrm{Au}-\mathrm{Ni}-\mathrm{TiO}_{2}$ micromotor (Wang et al. 2019). The microscopy images represent the efficient interactions leading to photodegradation reaction of the microplastics on the surface of the micromotor

\section{Photoreaction mechanism over the micromotor}

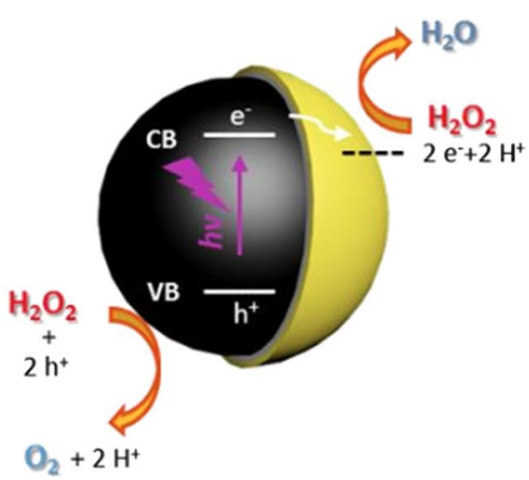

Interactions between the micromotor and microplastics during the treatment time

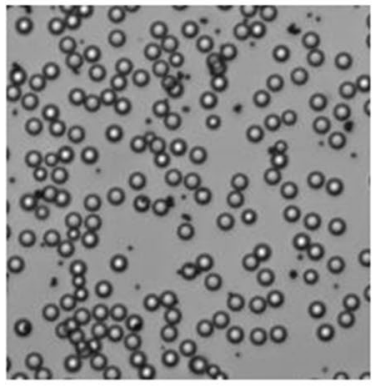

$0 \mathrm{~s}$

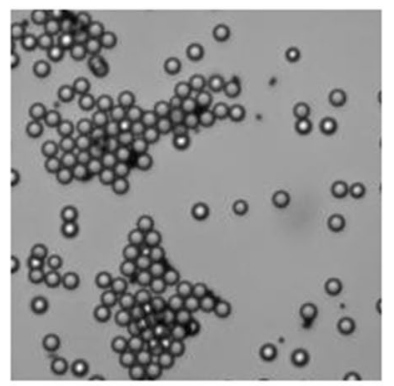

$60 \mathrm{~s}$

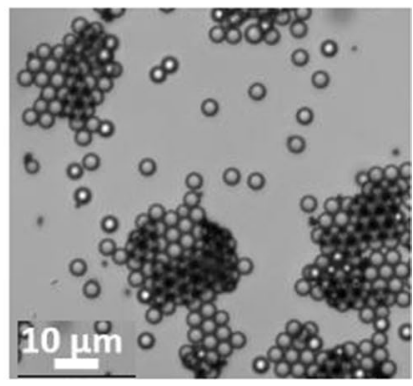

$120 \mathrm{~s}$ 
synthetic macroplastics (Ahmed et al. 2018; Bettas Ardisson et al. 2014).

Polyethylene microplastics fragmentation and size alteration ingested by Antarctic Krill (Euphausiasuperba), a planktonic crustacean, were studied by a group of environmentalists in Australia (Dawson et al. 2018). The mechanism of fragmentation and type of interactions between microplastics and zooplankton, in which biota-facilitated degradation occurs, still remains unclear but the experiments confirmed that smaller microplastics are much easily fragmented under environmental conditions (Ter Halle et al. 2016). Electron microscopic evidences confirmed the shrinking of polyethylene microplastics through fragmentation, where the physical size decreased from $\sim 31 \mu \mathrm{m}$ for
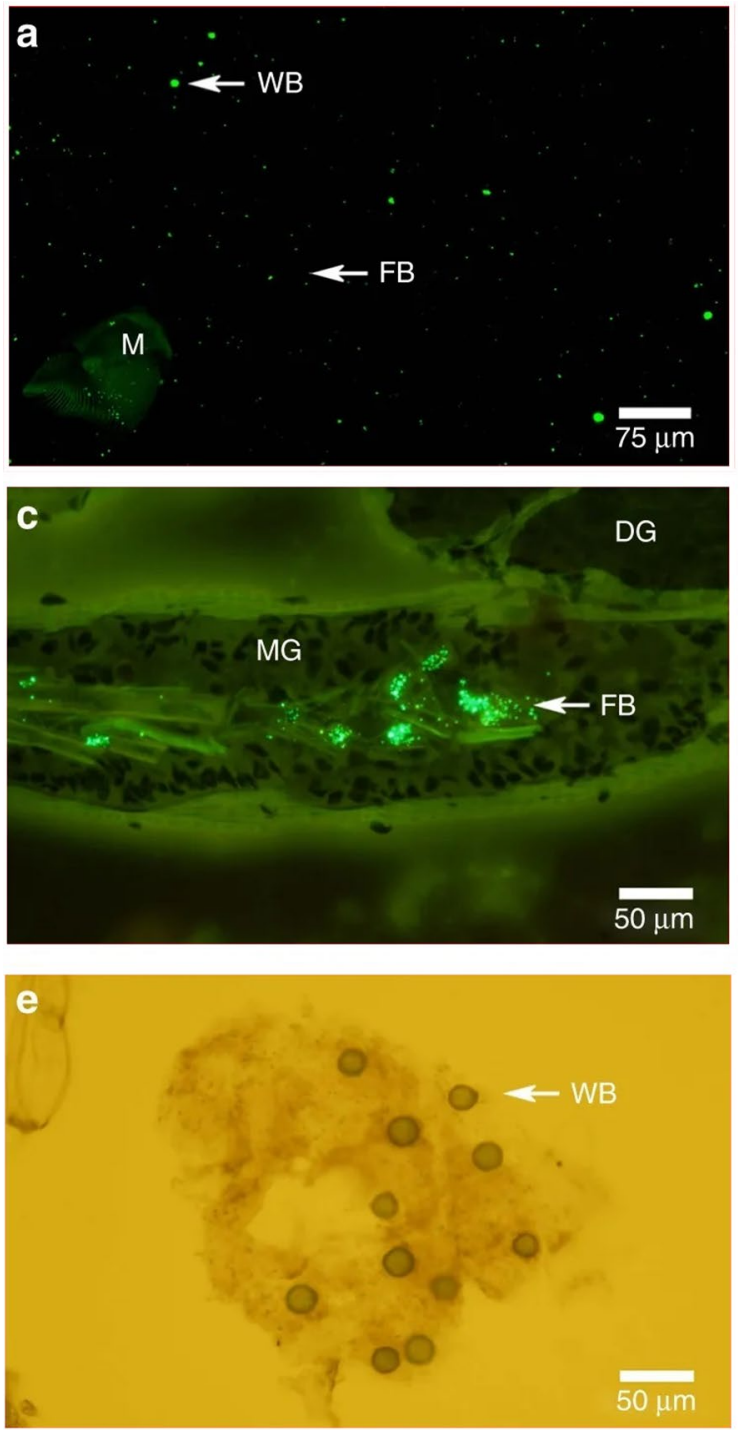

Fig. 11 Fate of microplastics ingested by Antarctic krill. Microplastics on a filter paper isolated from digested krill with auto-fluorescent mandible (a), digestive gland tissue (b), midgut and digestive gland tissue (c), mandible with the fragments embedded into the surface (d), and fecal pellet with microplastics under bright-field and fluores- the microplastics to less than $1 \mu \mathrm{m}$ for the fragmentation products (Fig. 11) (Dawson et al. 2018). The findings thus provide evidence for the biologically-mediated transformation of microplastics to nanoplastics.

The preliminary results of a four-month study on removal of high-density polyethylene secondary microplastics in seawater using two types of indigenous marine communities including Agios consortium and Souda consortium were published by Cocca et al. (2017). According to the recorded weight reduction results, the Souda consortium was more efficient. Interestingly, their results on monitoring the cell content and populations suggested that microplastics acted as a rich carbon source to feed the organisms. While the protein content of both communities decreased during the
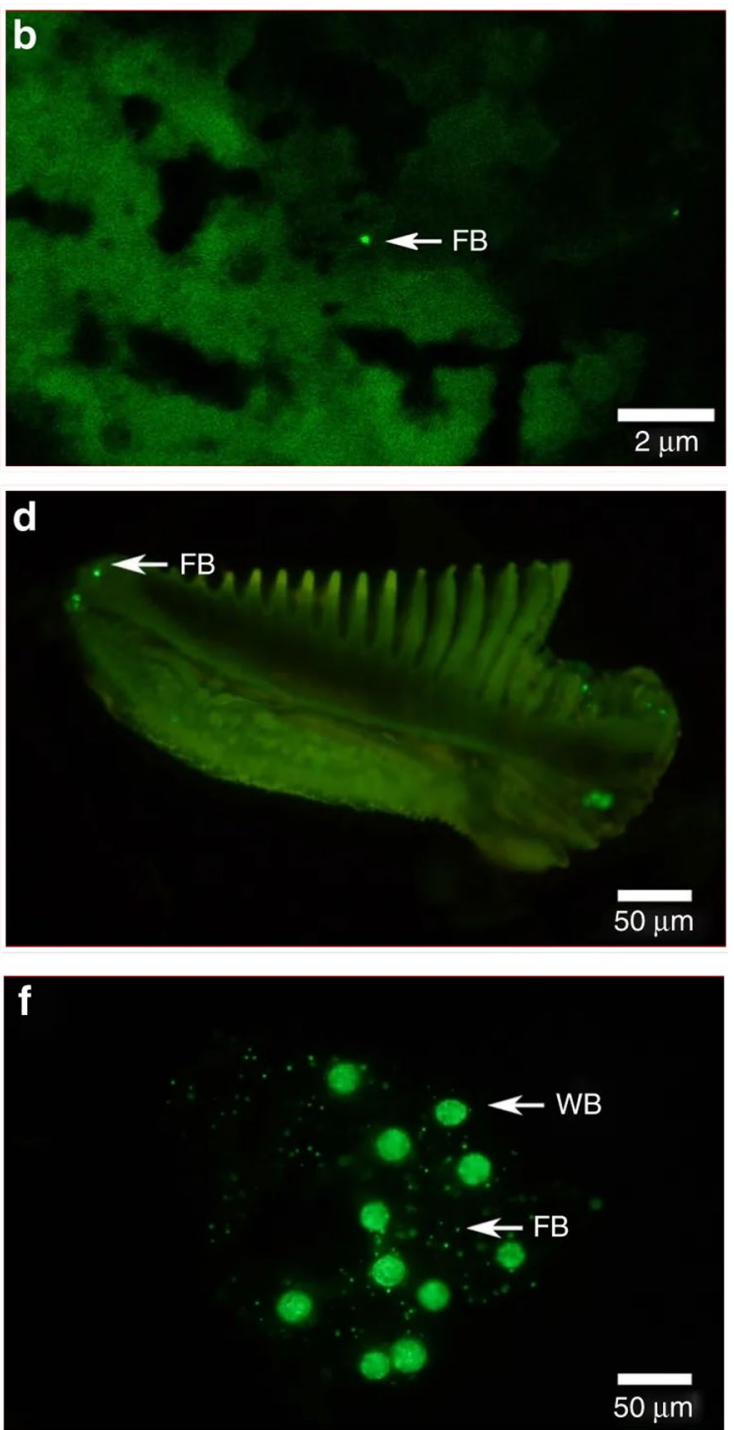

cence microscopy (f). This figure typically represents the pathway of microplastics transformation to nanoplastics inside the organism. $W B$ whole bead, $F B$ fragmented bead, $M$ mandible, $D G$ digestive gland, $M G$ midgut (Dawson et al. 2018) 

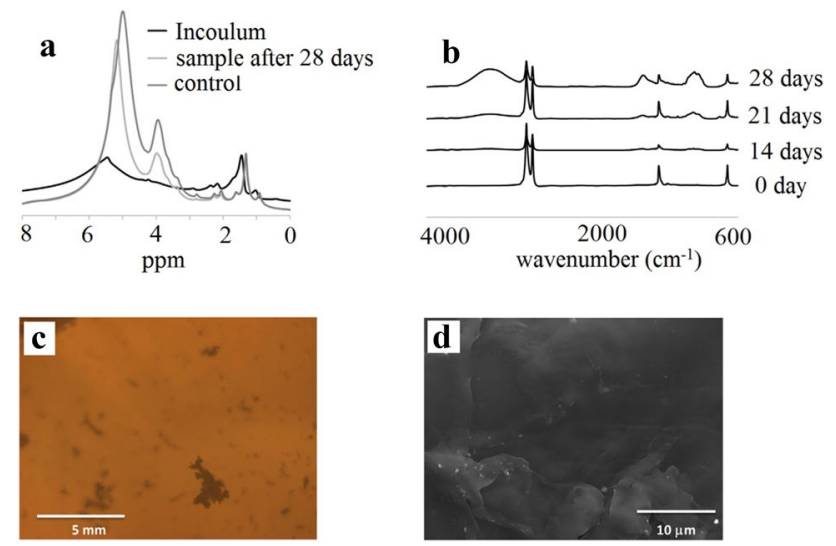

Fig. 12 Structural and morphological changes of the treated microplastics through biodegradation over fungus Z. maritimum in a batch reactor model (Paço et al. 2017). a NMR spectra, b FTIR patterns, c optical images and d electron microscopy images of the treated microplastics after 28 days. NMR: nuclear magnetic resonance. FTIR: Fourier transform infrared

experiment, the increase in cell's carbohydrate content implies enhancement in microbial tendency to adhere to the microplastics surfaces, which is the first step in microbial polymer degradation (Sivan 2011).

An important concern about the microplastics is their small size and negligible weight which enables them to easily spread over the long distances by wind-driven free ocean surface layer movements (Ivleva et al. 2017). Studies have also indicated that microplastics in sediments are normally in the range of 0-3146 particles $/ \mathrm{kg}$ of dry weight sediment, which highlights the urgent need of designing comprehensive experimental routes for the removal from aquatic ecosystems (Maes et al. 2017). The growth of microbial assemblages on the surface of microplastics should form a new platform prone to settle other organisms like microscopic fungi and microalgae. Although these microorganism communities can probably catalyze the metabolic reactions of microplastics resulting in their further biodegradation, the transport of nonnative organisms, which does not naturally occur in such environments, can induce negative effects on marine ecosystems variety (Urbanek et al. 2018).

Paço et al. (2017) explored the capability of fungus Zalerion maritimum, a naturally occurring fungus in marine ecosystems, for the polyethylene microplastics biodegradation based on mass and size variations of the microplastics in a batch reactor (Fig. 12). They measured the concentration of the contaminant at various time intervals to recognize the reaction rate order and found that biodegradation kinetics of the microplastics obeys to fractional order which can be described in terms of the complex mechanism expected for such reactions (Boudart and Djéga-Mariadassou 2014).
The evidences from biological content measurements, such as protein reduction and carbohydrate increase with exposure time, revealed that the $Z$. maritimum community possibly uses the microplastics as a nutrient source, an identical finding described earlier (Sivan 2011). Noteworthily, the results of the electron and optical microscopy clearly revealed that the biological compounds were present on the surface of the microplastic pellets, typically, highlighting the aforementioned potential of such organisms for triggering the effective biological degradation of microplastics from their surfaces. From FTIR analysis, the increases in the new bands' intensity appearing at regions 3700-3000, $1700-1500 \mathrm{~cm}^{-1}$, and $1200-950 \mathrm{~cm}^{-1}$, are, respectively, attributed to the hydroperoxide and hydroxyl groups, carbonyl groups, and double bonds, implying the oxidative degradation of polyethylene microplastics. Such variations were already observed in another work in which low-density polyethylene microplastics were photocatalytically removed from wastewater under visible light (Tofa et al. 2019).

\section{Microplastic removal by bacteria}

Auta et al. (2017) investigated the removal of different microplastics composed of polyethylene, polystyrene, polyethylene terephthalate and polypropylene by Bacillus cereus and Bacillus gottheilii, two types of Bacillus bacterial strains isolated from mangrove sediments (Fig. 13). In addition to scanning the morphological and structural changes using electron microscopy and FTIR analyses, the rate of biodegradation was assessed via measuring the microplastics weight loss. The fastest mass reduction (0.0019/ day) and shortest degradation half-life (363.16 days) was found using $B$. cereus isolate and polystyrene microplastics, whereas $B$. gottheilii on polyethylene gave $0.0016 /$ day and 431.25 days. Microplastics biodegradation can also be monitored performed by scanning electron microscopy (SEM), where several cracks, holes and erosions were observed (Sowmya et al. 2014). By comparing the degradation results, bond cleavages and chemical alterations scanned by FTIR analysis, $B$. gottheilii appeared as a better potential microplastic degrader.

\section{Microplastic ingestion}

The number of papers discussing microplastics ingestion by organisms as a removal strategy is limited (Arossa et al. 2019; Cole et al. 2013; Hall et al. 2015). Based on the results of coherent anti-Stokes Raman scattering and fluorescence microscopy, Cole et al. (2013) suggested that zooplankton's function and health can be negatively affected by micro-sized polystyrene plastic debris. They also stated 
Fig. 13 Removal of different types of microplastics over two types of Bacillus bacterial strains, $B$. cereus and $B$. gottheilii (Auta et al. 2017). a Initial growth of bacterial population implies the use of microplastics as nutrient. The further decrease exhibits the progress in biodegradation. $\mathbf{b}$ Appearance of new bands in the Fourier transform infrared (FTIR) spectra of the treated samples confirms microplastic biodegradation. c Scanning electron microscopy (SEM) images show numerous erosions and cracks on the surface of the microplastics after the biological treatment
Microplastic bacterial degradation
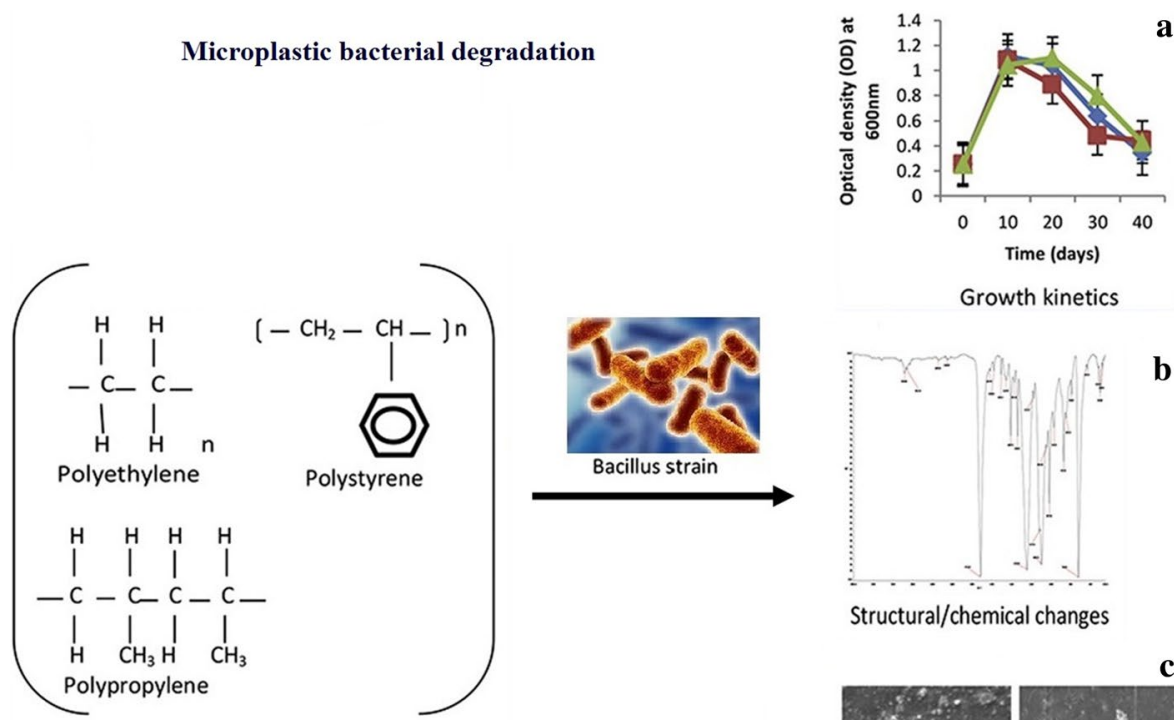

Growth kinetics

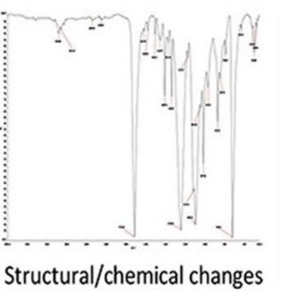

b
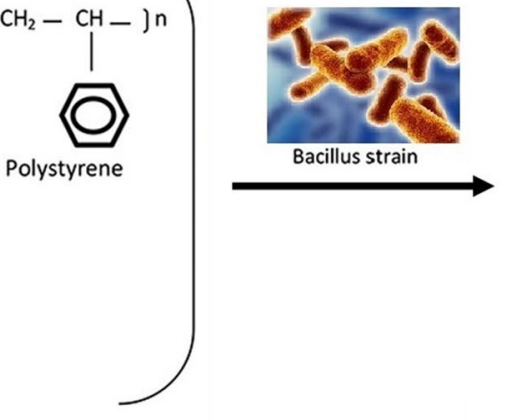

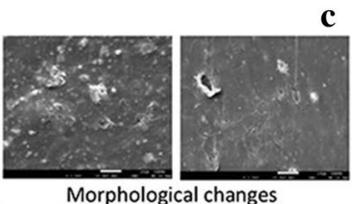

Morphological changes that microplastics adherence to the external carapace of zooplankton considerably influenced the organism feeding, a crucial hindrance factor against normal growth conditions in marine wildlife (Van Franeker et al. 2011). Although this work was not aimed to introduce a way for microplastics removal, the results reveal the high capacity of zooplankton to remove $1.7-30.6 \mu \mathrm{m}$ polystyrene microplastics through uptake and ingestion inside the organism body, in which their intestinal tracts can hold the microplastics up to 7 days after entrance.

Hall et al. (2015) also reported capture and ingestion of polypropylene microplastics by scleractinian corals with a

\section{Microplastic remediation using clams}

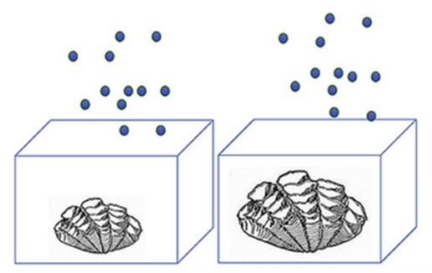

Factor 1: Two size classes of T. Maxima

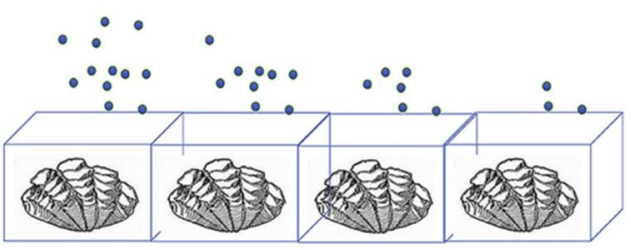

Factor 2: Four concentrations of microplastic

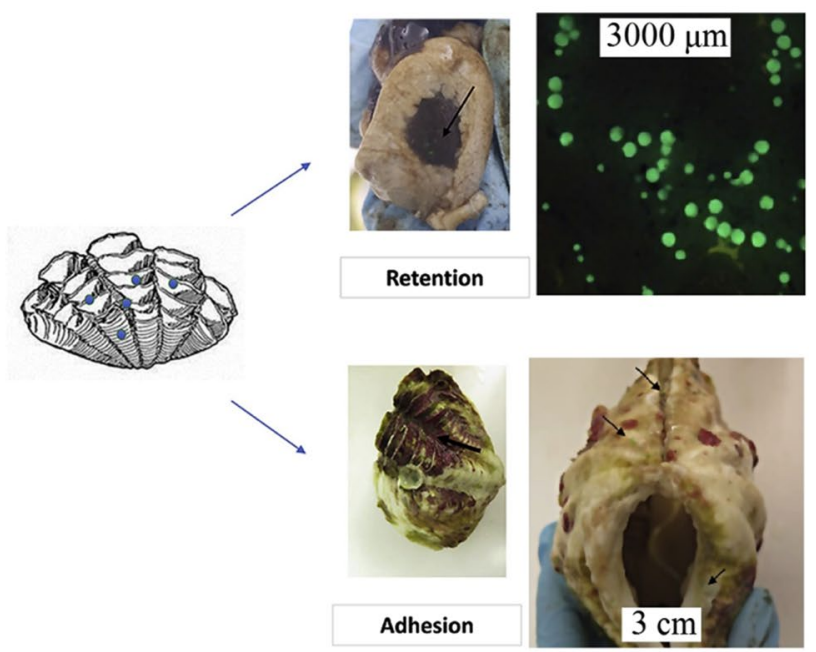

Fig. 14 Polyethylene microplastics removal from wastewater over Red Sea clams (Arossa et al. 2019). Experiments involved four concentrations of microplastics over two different sizes of T. Maxima clams. Removal was done by retention, trapping inside the clam, and adhesion on the surface 
consumption rate of $50 \mu \mathrm{g}$ plastic $\mathrm{cm}^{-2} / \mathrm{h}$, and evidenced the presence of microplastics in mesenterial tissue within gut cavity of the coral for at least $24 \mathrm{~h}$. However, the mechanism of the affection which potentially interferes with coral growth, physiology, and survival still remains unclear. This research was important since inshore coral reefs ecosystem, the coastal areas, is easily available as touristic regions for long periods and many of water treatment plants also daily release their effluents containing microplastics debris, as mentioned above, to such environments.

The evaluation of the capability of the Red Sea giant clam, Tridacna maxima, for the removal of 53-500 $\mu \mathrm{m}$ polyethylene microplastics from wastewater (Fig. 14) has been reported by Arossa et al. (2019). Their results revealed the key role of clam's shells to remove the microplastics by sorption on the surface, as they resulted in $66.03 \%$ of removal from the wastewater. The authors suggested that this marine biota can be used for rapid removal of the anthropogenic microplastics debris from aquatic surfaces in the regions with low concentration of microplastics, a fact partly demonstrated by previous researchers (Martí et al. 2017). The effect of microplastics initial concentration and clam's size on the removal rates through active, microplastics retention inside the body, and/or passive, trapping by the shells, pathways was investigated. The results indicated that big clams tend to retain bigger microplastics inside their bodies, while small clams did not show any sharp preference for them. Moreover, at any concentration, the microplastics easily penetrated into the digestive system of all clams used in this experiment. According to their measurements, the passive route of removal accounts averagely for $35.95 \%$ of the microplastics, leading to a significant increase in the density of microplastics attached to clam's shells and normally, the larger clams adsorb higher concentrations of the microplastics. As a whole, this research opened a new window for environmental pollution management making use of the marine biota possessing complex surface and structure. But, finding the mechanism of interactions between the microplastics and organisms needs to be explored. Accordingly, we will be able to opt the type of sorbent biota and operational conditions for achieving the highest microplastics removal efficiency.

In brief, microplastics can provide a platform to grow a variety of microbial assemblages. Biological degradation using microorganisms, e.g., zooplankton, marine fungi and bacterial strains, has been confirmed to be suitable to remove microplastics at low concentrations. The mechanism of interactions and fragmentation is not well understood. Microplastics, in the most of case studies, acted as a nutrient source for the organisms. This could not convince us to consider "ingestion" as a removal strategy to treat the microplastic pollutions.

A comparison of treatment methods for removal of the microplastics from the environment is represented in Table 3 . The table briefly summarizes the advantages, disadvantages, and the efficiency of the projects utilized for the last few years. It is obvious that membrane-included technologies are still the most reliable techniques to remove microplastics in the practical applications. However, it seems that finding the suitable alternatives to couple with these methodologies is the main goal of the ongoing projects.

\section{Conclusion}

After short surveying on sources, occurrence, and transport pathways of microplastics, recent studies on three major approaches including chemical, biological, and physical methods to remove them from the environments have been summarized. Sorption and filtration processes coupled with membrane bioreactors lead to removing a high percentage of microplastics in the influents entering into the water treatment plants but these systems acted themselves as daily microplastic sources since the effluents are directly released to aquatic environments. Conventional activated sludge strategy is also used to treat wastewaters in water treatment plants but shows lower efficiency than membrane bioreactor technologies which makes it a less popular methodology. Electrocoagulation and agglomeration have also become reliable techniques for easy separation of microplastics but are needed to be coupled with eminent extra filtration stages. Photocatalytic degradation using $\mathrm{TiO}_{2}$ and $\mathrm{ZnO}$ semiconductors is experimentally revealed to be a suitable method among the aforementioned strategies. FTIR and electron microscopy analyses are widely served to elucidate any structural alterations during the degradation process. Biological degradation has been investigated over the bacterial strains and marine organisms. Appearance of hydroperoxide and hydroxyl groups, carbonyl groups, and double-bond characteristic bands in the FTIR patterns of the treated microplastics suggests the oxidative mechanism for 


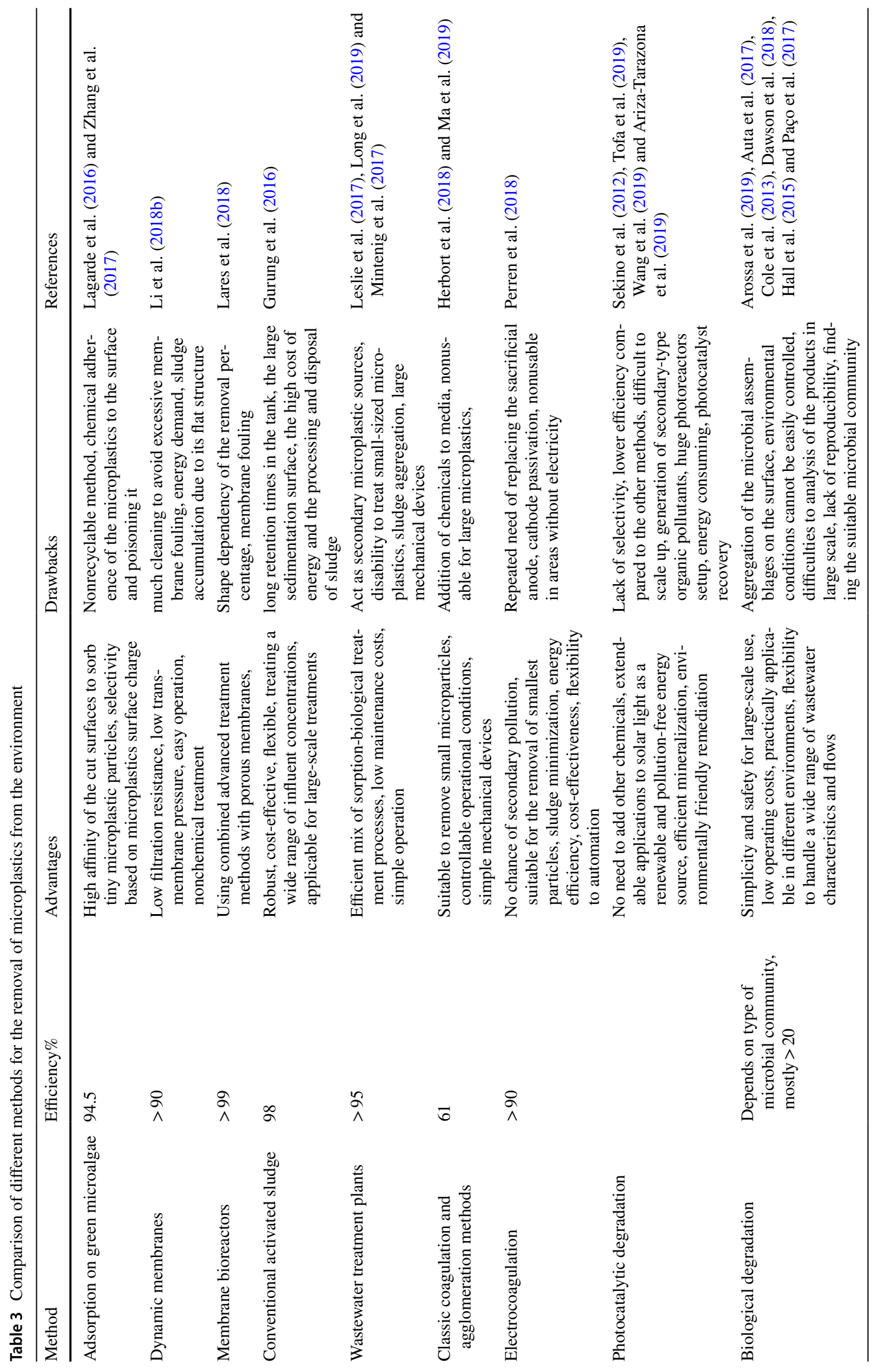


biological removal. Ingestion by organisms has still not considered as a removal strategy but Red Sea giant clam exhibits good potential for microplastics sorption on the shells besides its degradation in digestive system.

Acknowledgements This work is financially supported by SAFEA of China (High-End Foreign Expert Project \# G20190241013) and the scientific research startup fund of Shaanxi University of Science and Technology.

\section{References}

Ahmed T, Shahid M, Azeem F, Rasul I, Shah AA, Noman M, Hameed A, Manzoor N, Manzoor I, Muhammad S (2018) Biodegradation of plastics: current scenario and future prospects for environmental safety. Environ Sci Pollut Res 25(8):7287-7298. https://doi. org/10.1007/s11356-018-1234-9

Akbal F, Camc1 S (2011) Copper, chromium and nickel removal from metal plating wastewater by electrocoagulation. Desalination 269(1-3):214-222. https://doi.org/10.1016/j.desal.2010.11.001

Andrady AL (2011) Microplastics in the marine environment. Mar Pollut Bull 62(8):1596-1605. https://doi.org/10.1016/j.marpo lbul.2011.05.030

Andrady AL (2017) The plastic in microplastics: a review. Mar Pollut Bull 119(1):12-22. https://doi.org/10.1016/j.marpo lbul.2017.01.082

Ariza-Tarazona MC, Villarreal-Chiu JF, Barbieri V, Siligardi C, Cedillo-González EI (2019) New strategy for microplastic degradation: green photocatalysis using a protein-based porous $\mathrm{N}-\mathrm{TiO}_{2}$ semiconductor. Ceram Int 45(7):9618-9624. https://doi. org/10.1016/j.ceramint.2018.10.208

Arossa S, Martin C, Rossbach S, Duarte CM (2019) Microplastic removal by red sea giant clam (Tridacna maxima). Environ Pollut 252:1257-1266. https://doi.org/10.1016/j.envpol.2019.05.149

Au SY, Bruce TF, Bridges WC, Klaine SJ (2015) Responses of Hyalella azteca to acute and chronic microplastic exposures. Environ Toxicol Chem 34(11):2564-2572. https://doi.org/10.1002/ etc. 3093

Auta H, Emenike C, Fauziah S (2017) Screening of Bacillus strains isolated from mangrove ecosystems in Peninsular Malaysia for microplastic degradation. Environ Pollut 231:1552-1559. https ://doi.org/10.1016/j.envpol.2017.09.043

Ballent A, Purser A, de Jesus Mendes P, Pando S, Thomsen L (2012) Physical transport properties of marine microplastic pollution. Biogeosci Discuss. https://doi.org/10.5194/bgd-9-18755-2012

Beljanski A (2016) Efficiency and effectiveness of a low-cost, selfcleaning microplastic filtering system for wastewater treatment plants. 2016 NCUR

Besseling E, Wang B, Lürling M, Koelmans AA (2014) Nanoplastic affects growth of $S$. obliquus and reproduction of $D$. magna. Environ Sci Technol 48(20):12336-12343. https://doi. org/10.1021/es503001d

Bettas Ardisson G, Tosin M, Barbale M, Degli-Innocenti F (2014) Biodegradation of plastics in soil and effects on nitrification activity. A laboratory approach. Front Microbiol 5:710-723. https://doi. org/10.3389/fmicb.2014.00710

Bhattacharya P, Lin S, Turner JP, Ke PC (2010) Physical adsorption of charged plastic nanoparticles affects algal photosynthesis. J Phys Chem C 114(39):16556-16561. https://doi.org/10.1021/ jp1054759
Boudart M, Djéga-Mariadassou G (2014) Kinetics of heterogeneous catalytic reactions. Princeton University Press, Princeton. https ://doi.org/10.1007/978-3-662-05981-4_13

Brandon J, Goldstein M, Ohman MD (2016) Long-term aging and degradation of microplastic particles: comparing in situ oceanic and experimental weathering patterns. Mar Pollut Bull 110(1):299308. https://doi.org/10.1016/j.marpolbul.2016.06.048

Browne MA, Crump P, Niven SJ, Teuten E, Tonkin A, Galloway T, Thompson R (2011) Accumulation of microplastic on shorelines worldwide: sources and sinks. Environ Sci Technol 45(21):91759179. https://doi.org/10.1021/es201811s

Browne MA, Niven SJ, Galloway TS, Rowland SJ, Thompson RC (2013) Microplastic moves pollutants and additives to worms, reducing functions linked to health and biodiversity. Curr Biol 23(23):2388-2392. https://doi.org/10.1016/j.cub.2013.10.012

Carr SA, Liu J, Tesoro AG (2016) Transport and fate of microplastic particles in wastewater treatment plants. Water Res 91:174-182. https://doi.org/10.1016/j.watres.2016.01.002

Chorghe D, Sari MA, Chellam S (2017) Boron removal from hydraulic fracturing wastewater by aluminum and iron coagulation: mechanisms and limitations. Water Res 126:481-487. https:// doi.org/10.1016/j.watres.2017.09.057

Cocca M, Di Pace E, Errico ME, Gentile G, Montarsolo A, Mossotti R (2017) Proceedings of the international conference on microplastic pollution in the mediterranean sea. Springer, Berlin

Cole M, Lindeque P, Halsband C, Galloway TS (2011) Microplastics as contaminants in the marine environment: a review. Mar Pollut Bull 62(12):2588-2597. https://doi.org/10.1016/j.marpo lbul.2011.09.025

Cole M, Lindeque P, Fileman E, Halsband C, Goodhead R, Moger J, Galloway TS (2013) Microplastic ingestion by zooplankton. Environ Sci Technol 47(12):6646-6655. https://doi.org/10.1021/ es400663f

Colom X, Canavate J, Sunol J, Pages P, Saurina J, Carrasco F (2003) Natural and artificial aging of polypropylene-polyethylene copolymers. J Appl Polym Sci 87(10):1685-1692. https://doi. org/10.1002/app.11613

Corcoran PL, Norris T, Ceccanese T, Walzak MJ, Helm PA, Marvin CH (2015) Hidden plastics of Lake Ontario, Canada and their potential preservation in the sediment record. Environ Pollut 204:17-25. https://doi.org/10.1016/j.envpol.2015.04.009

Da Costa JP, Nunes AR, Santos PS, Girão AV, Duarte AC, RochaSantos T (2018) Degradation of polyethylene microplastics in seawater: insights into the environmental degradation of polymers. J Environ Sci Health Part A 53(9):866-875. https://doi. org/10.1080/10934529.2018.1455381

Dawson AL, Kawaguchi S, King CK, Townsend KA, King R, Huston WM, Nash SMB (2018) Turning microplastics into nanoplastics through digestive fragmentation by Antarctic krill. Nat Commun 9(1):1001. https://doi.org/10.1038/s41467-018-03465-9

Dris R, Gasperi J, Saad M, Mirande C, Tassin B (2016) Synthetic fibers in atmospheric fallout: a source of microplastics in the environment? Mar Pollut Bull 104(1-2):290-293. https://doi. org/10.1016/j.marpolbul.2016.01.006

Eriksen M, Lebreton LC, Carson HS, Thiel M, Moore CJ, Borerro JC, Galgani F, Ryan PG, Reisser J (2014) Plastic pollution in the world's oceans: more than 5 trillion plastic pieces weighing over 250,000 tons afloat at sea. PLoS ONE 9(12):111913-111927. https://doi.org/10.1371/journal.pone.0111913

Ersahin ME, Tao Y, Ozgun H, Gimenez JB, Spanjers H, van Lier JB (2017) Impact of anaerobic dynamic membrane bioreactor configuration on treatment and filterability performance. J Membr Sci 526:387-394. https://doi.org/10.1016/j.memsci.2016.12.057

Eskandarloo H, Kierulf A, Abbaspourrad A (2017) Light-harvesting synthetic nano-and micromotors: a review. Nanoscale 9(34):12218-12230. https://doi.org/10.1039/C7NR05166B 
Fasano E, Bono-Blay F, Cirillo T, Montuori P, Lacorte S (2012) Migration of phthalates, alkylphenols, bisphenol A and di (2-ethylhexyl) adipate from food packaging. Food Control 27(1):132138. https://doi.org/10.1016/j.foodcont.2012.03.005

Faure F, Demars C, Wieser O, Kunz M, De Alencastro LF (2015) Plastic pollution in Swiss surface waters: nature and concentrations, interaction with pollutants. Environ Chem 12(5):582-591. https ://doi.org/10.1071/EN14218

Galgani F, Hanke G, Werner S, De Vrees L (2013) Marine litter within the European marine strategy framework directive. ICES J Mar Sci 70(6):1055-1064. https://doi.org/10.1093/icesjms/fst122

Gilani AG, Taghvaei V, Rufchahi EM, Mirzaei M (2019) Tautomerism, solvatochromism, preferential solvation, and density functional study of some heteroarylazo dyes. J Mol Liq 273:392-407. https ://doi.org/10.1016/j.molliq.2018.10.054

Graham ER, Thompson JT (2009) Deposit-and suspension-feeding sea cucumbers (Echinodermata) ingest plastic fragments. J Exp Mar Biol Ecol 368(1):22-29. https://doi.org/10.1016/j.jembe .2008.09.007

Gregory MR (2009) Environmental implications of plastic debris in marine settings - entanglement, ingestion, smothering, hangers-on, hitch-hiking and alien invasions. Philos Trans R Soc B Biol Sci 364(1526):2013-2025. https://doi.org/10.1098/ rstb. 2008.0265

Gulmine J, Janissek P, Heise H, Akcelrud L (2003) Degradation profile of polyethylene after artificial accelerated weathering. Polym Degrad Stab 79(3):385-397. https://doi.org/10.1016/S0141 $-3910(02) 00338-5$

Gurung K, Ncibi MC, Fontmorin J-M, Särkkä H, Sillanpää M (2016) Incorporating submerged MBR in conventional activated sludge process for municipal wastewater treatment: a feasibility and performance assessment. J Membr Sci Technol. https://doi. org/10.4172/2155-9589.1000158

Hahladakis JN, Velis CA, Weber R, Iacovidou E, Purnell P (2018) An overview of chemical additives present in plastics: migration, release, fate and environmental impact during their use, disposal and recycling. J Hazard Mater 344:179-199. https://doi. org/10.1016/j.jhazmat.2017.10.014

Hall N, Berry K, Rintoul L, Hoogenboom M (2015) Microplastic ingestion by scleractinian corals. Mar Biol 162(3):725-732. https:// doi.org/10.1007/s00227-015-2619-7

Hämer J, Gutow L, Köhler A, Saborowski R (2014) Fate of microplastics in the marine isopod Idotea emarginata. Environ Sci Technol 48(22):13451-13458. https://doi.org/10.1021/es501385y

Harrison JP, Sapp M, Schratzberger M, Osborn AM (2011) Interactions between microorganisms and marine microplastics: a call for research. Mar Technol Soc J 45(2):12-20. https://doi. org/10.4031/MTSJ.45.2.2

Hazrat M, Rasul M, Khan MMK (2015) A study on thermo-catalytic degradation for production of clean transport fuel and reducing plastic wastes. Procedia Eng 105:865-876. https://doi. org/10.1016/j.proeng.2015.05.108

Herbort AF, Sturm MT, Fiedler S, Abkai G, Schuhen K (2018) Alkoxysilyl induced agglomeration: a new approach for the sustainable removal of microplastic from aquatic systems. J Polym Environ 26(11):4258-4270. https://doi.org/10.1007/s10924-018-1287-3

Hirai H, Takada H, Ogata Y, Yamashita R, Mizukawa K, Saha M, Kwan C, Moore C, Gray H, Laursen D (2011) Organic micropollutants in marine plastics debris from the open ocean and remote and urban beaches. Mar Pollut Bull 62(8):1683-1692. https://doi. org/10.1016/j.marpolbul.2011.06.004

Horton AA, Dixon SJ (2018) Microplastics: an introduction to environmental transport processes. Wiley Interdiscip Rev Water 5(2):1268-1283. https://doi.org/10.1002/wat2.1268

Horton AA, Svendsen C, Williams RJ, Spurgeon DJ, Lahive E (2017a) Large microplastic particles in sediments of tributaries of the
River Thames, UK-Abundance, sources and methods for effective quantification. Mar Pollut Bull 114(1):218-226. https://doi. org/10.1016/j.marpolbul.2016.09.004

Horton AA, Walton A, Spurgeon DJ, Lahive E, Svendsen C (2017b) Microplastics in freshwater and terrestrial environments: evaluating the current understanding to identify the knowledge gaps and future research priorities. Sci Total Environ 586:127-141. https ://doi.org/10.1016/j.scitotenv.2017.01.190

Hu C, Liu H, Chen G, Qu J (2012) Effect of aluminum speciation on arsenic removal during coagulation process. Sep Purif Technol 86:35-40. https://doi.org/10.1016/j.seppur.2011.10.017

Huff J, Chan P, Melnick R (2010) Clarifying carcinogenicity of ethylbenzene. Regul Toxicol Pharmacol 58(2):167-169. https://doi. org/10.1016/j.yrtph.2010.08.011

Ivleva NP, Wiesheu AC, Niessner R (2017) Microplastic in aquatic ecosystems. Angew Chem Int Ed 56(7):1720-1739

Jiang J-Q (2018) Occurrence of microplastics and its pollution in the environment: a review. Sustain Prod Consum 13:16-23. https:// doi.org/10.1016/j.spc.2017.11.003

Jin L, Zhang G, Tian H (2014) Current state of sewage treatment in China. Water Res 66:85-98. https://doi.org/10.1016/j.watre s.2014.08.014

Karami A, Romano N, Galloway T, Hamzah H (2016) Virgin microplastics cause toxicity and modulate the impacts of phenanthrene on biomarker responses in African catfish (Clarias gariepinus). Environ Res 151:58-70. https://doi.org/10.1016/j. envres.2016.07.024

Kirstein IV, Kirmizi S, Wichels A, Garin-Fernandez A, Erler R, Martin L, Gerdts G (2016) Dangerous hitchhikers? Evidence for potentially pathogenic Vibrio spp. on microplastic particles. Mar Environ Res 120:1-8. https://doi.org/10.1016/j.maren vres.2016.07.004

Knoblock M, Sutton P, Mishra P, Gupta K, Janson A (1994) Membrane biological reactor system for treatment of oily wastewaters. Water Environ Res 66(2):133-139. https://doi. org/10.2175/WER.66.2.6

Lagarde F, Olivier O, Zanella M, Daniel P, Hiard S, Caruso A (2016) Microplastic interactions with freshwater microalgae: heteroaggregation and changes in plastic density appear strongly dependent on polymer type. Environ Pollut 215:331-339. https ://doi.org/10.1016/j.envpol.2016.05.006

Lares M, Ncibi MC, Sillanpää M, Sillanpää M (2018) Occurrence, identification and removal of microplastic particles and fibers in conventional activated sludge process and advanced MBR technology. Water Res 133:236-246. https://doi.org/10.1016/j. watres.2018.01.049

Lau O-W, Wong S-K (2000) Contamination in food from packaging material. J Chromatogr A 882(1-2):255-270. https://doi. org/10.1016/S0021-9673(00)00356-3

Law KL, Morét-Ferguson SE, Goodwin DS, Zettler ER, DeForce E, Kukulka T, Proskurowski G (2014) Distribution of surface plastic debris in the eastern Pacific Ocean from an 11-year data set. Environ Sci Technol 48(9):4732-4738. https://doi.org/10.1021/ es4053076

Lee KE, Morad N, Teng TT, Poh BT (2012) Development, characterization and the application of hybrid materials in coagulation/ flocculation of wastewater: a review. Chem Eng J 203:370-386. https://doi.org/10.1016/j.cej.2012.06.109

Lei L, Wu S, Lu S, Liu M, Song Y, Fu Z, Shi H, Raley-Susman KM, He D (2018) Microplastic particles cause intestinal damage and other adverse effects in zebrafish Danio rerio and nematode Caenorhabditis elegans. Sci Total Environ 619:1-8. https://doi. org/10.1016/j.scitotenv.2017.11.103

Leslie H, Brandsma S, Van Velzen M, Vethaak A (2017) Microplastics en route: field measurements in the Dutch river delta and Amsterdam canals, wastewater treatment plants, North Sea sediments 
and biota. Environ Int 101:133-142. https://doi.org/10.1016/j. envint.2017.01.018

Li S, Xu S, He L, Xu F, Wang Y, Zhang L (2010) Photocatalytic degradation of polyethylene plastic with polypyrrole/ $/ \mathrm{TiO}_{2}$ nanocomposite as photocatalyst. Polym Plast Technol Eng 49(4):400-406. https://doi.org/10.1080/03602550903532166

Li J, Liu H, Chen JP (2018a) Microplastics in freshwater systems: a review on occurrence, environmental effects, and methods for microplastics detection. Water Res 137:362-374. https://doi. org/10.1016/j.watres.2017.12.056

Li L, Xu G, Yu H, Xing J (2018b) Dynamic membrane for microparticle removal in wastewater treatment: performance and influencing factors. Sci Total Environ 627:332-340. https://doi. org/10.1016/j.scitotenv.2018.01.239

Liang W, Luo Y, Song S, Dong X, Yu X (2013) High photocatalytic degradation activity of polyethylene containing polyacrylamide grafted $\mathrm{TiO}_{2}$. Polym Degrad Stab 98(9):1754-1761. https://doi. org/10.1016/j.polymdegradstab.2013.05.027

Liu P, Qian L, Wang H, Zhan X, Lu K, Gu C, Gao S (2019) New insights into the aging behavior of microplastics accelerated by advanced oxidation processes. Environ Sci Technol 53:35793588. https://doi.org/10.1021/acs.est.9b00493

Long Z, Pan Z, Wang W, Ren J, Yu X, Lin L, Lin H, Chen H, Jin X (2019) Microplastic abundance, characteristics, and removal in wastewater treatment plants in a coastal city of China. Water Res 155:255-265. https://doi.org/10.1016/j.watres.2019.02.028

Lu Y, Zhang Y, Deng Y, Jiang W, Zhao Y, Geng J, Ding L, Ren H (2016) Uptake and accumulation of polystyrene microplastics in zebrafish (Danio rerio) and toxic effects in liver. Environ Sci Technol 50(7):4054-4060. https://doi.org/10.1021/acs. est.6b00183

Lwanga EH, Gertsen H, Gooren H, Peters P, Salánki T, van der Ploeg M, Besseling E, Koelmans AA, Geissen V (2017) Incorporation of microplastics from litter into burrows of Lumbricus terrestris. Environ Pollut 220:523-531. https://doi.org/10.1016/j. envpol.2016.09.096

Ma B, Xue W, Ding Y, Hu C, Liu H, Qu J (2019) Removal characteristics of microplastics by Fe-based coagulants during drinking water treatment. J Environ Sci 78:267-275. https:// doi.org/10.1016/j.jes.2018.10.006

MacArthur DE, Waughray D, Stuchtey M (2016) The new plastics economy, rethinking the future of plastics. World Economic Forum

Maes T, Van der Meulen MD, Devriese LI, Leslie HA, Huvet A, Frère L, Robbens J, Vethaak AD (2017) Microplastics baseline surveys at the water surface and in sediments of the North-East Atlantic. Front Mar Sci 4:135-149. https://doi.org/10.3389/ fmars.2017.00135

Martí E, Martin C, Cózar A, Duarte CM (2017) Low abundance of plastic fragments in the surface waters of the Red Sea. Front Mar Sci 4:333-345. https://doi.org/10.3389/fmars.2017.00333

Martins MJF, Mota CF, Pearson GA (2013) Sex-biased gene expression in the brown alga Fucus vesiculosus. BMC Genom 14(1):294-326. https://doi.org/10.1186/1471-2164-14-294

Meeker JD, Sathyanarayana S, Swan SH (2009) Phthalates and other additives in plastics: human exposure and associated health outcomes. Philos Trans R Soc B Biol Sci 364(1526):20972113. https://doi.org/10.1098/rstb.2008.0268

Mintenig S, Int-Veen I, Löder MG, Primpke S, Gerdts G (2017) Identification of microplastic in effluents of waste water treatment plants using focal plane array-based micro-Fourier-transform infrared imaging. Water Res 108:365-372. https://doi. org/10.1016/j.watres.2016.11.015

Murphy J (2001) Additives for plastics handbook. Elsevier, Amsterdam. https://doi.org/10.1016/b978-1-85617-370-4.x5000-3
Murphy F, Ewins C, Carbonnier F, Quinn B (2016) Wastewater treatment works (WwTW) as a source of microplastics in the aquatic environment. Environ Sci Technol 50(11):5800-5808. https://doi.org/10.1021/acs.est.5b05416

Nicole L, Boissière C, Grosso D, Hesemann P, Moreau J, Sanchez C (2004) Advanced selective optical sensors based on periodically organized mesoporous hybrid silica thin films. Chem Commun 20:2312-2313. https://doi.org/10.1039/b408869g

Nizzetto L, Futter M, Langaas S (2016) Are agricultural soils dumps for microplastics of urban origin? Environ Sci Technol 50(20):10777-10779. https://doi.org/10.1021/acs.est.6b04140

Nobre C, Santana M, Maluf A, Cortez F, Cesar A, Pereira C, Turra A (2015) Assessment of microplastic toxicity to embryonic development of the sea urchin Lytechinus variegatus (Echinodermata: echinoidea). Mar Pollut Bull 92(1-2):99-104. https ://doi.org/10.1016/j.marpolbul.2014.12.050

Nolte TM, Hartmann NB, Kleijn JM, Garnæs J, van de Meent D, Hendriks AJ, Baun A (2017) The toxicity of plastic nanoparticles to green algae as influenced by surface modification, medium hardness and cellular adsorption. Aquat Toxicol 183:11-20. https://doi.org/10.1016/j.aquatox.2016.12.005

Paço A, Duarte K, da Costa JP, Santos PS, Pereira R, Pereira M, Freitas AC, Duarte AC, Rocha-Santos TA (2017) Biodegradation of polyethylene microplastics by the marine fungus Zalerion maritimum. Sci Total Environ 586:10-15. https:// doi.org/10.1016/j.scitotenv.2017.02.017

Pathak VM (2017) Review on the current status of polymer degradation: a microbial approach. Bioresour Bioprocess 4(1):15-42. https://doi.org/10.1186/s40643-017-0145-9

Paul-Pont I, Lacroix C, Fernández CG, Hégaret H, Lambert C, Le Goïc N, Frère L, Cassone A-L, Sussarellu R, Fabioux C (2016) Exposure of marine mussels Mytilus spp. to polystyrene microplastics: toxicity and influence on fluoranthene bioaccumulation. Environ Pollut 216:724-737. https://doi.org/10.1016/j.envpo 1.2016.06.039

Perren W, Wojtasik A, Cai Q (2018) Removal of microbeads from wastewater using electrocoagulation. ACS Omega 3(3):33573364. https://doi.org/10.1021/acsomega.7b02037

Piringer OG, Baner AL (2008) Plastic packaging materials for food: barrier function, mass transport, quality assurance, and legislation. Wiley, Hoboken. https://doi.org/10.1002/9783527613281

Prata JC (2018) Airborne microplastics: consequences to human health? Environ Pollut 234:115-126. https://doi.org/10.1016/j. envpol.2017.11.043

Rios LM, Moore C, Jones PR (2007) Persistent organic pollutants carried by synthetic polymers in the ocean environment. Mar Pollut Bull 54(8):1230-1237. https://doi.org/10.1016/j.marpo lbul.2007.03.022

Ritchie H, Roser M (2018) Plastic pollution. https://ourworldindata. org/plastic-pollution

Sekino T, Takahashi S, Takamasu K (2012) Fundamental study on nanoremoval processing method for microplastic structures using photocatalyzed oxidation. Key Eng Mater (Trans Tech Publ). https://doi.org/10.4028/www.scientific.net/KEM.523-524.610

Setälä O, Fleming-Lehtinen V, Lehtiniemi M (2014) Ingestion and transfer of microplastics in the planktonic food web. Environ Pollut 185:77-83. https://doi.org/10.1016/j.envpol.2013.10.013

Shirasaki N, Matsushita T, Matsui Y, Marubayashi T (2016) Effect of aluminum hydrolyte species on human enterovirus removal from water during the coagulation process. Chem Eng J 284:786-793. https://doi.org/10.1016/j.cej.2015.09.045

Simoneau C, Van den Eede L, Valzacchi S (2012) Identification and quantification of the migration of chemicals from plastic baby bottles used as substitutes for polycarbonate. Food Addit Contam Part A 29(3):469-480. https://doi.org/10.1080/19440 049.2011 .644588 
Sivan A (2011) New perspectives in plastic biodegradation. Curr Opin Biotechnol 22(3):422-426. https://doi.org/10.1016/j.copbi o.2011.01.013

Sowmya H, Ramalingappa M, Thippeswamy B (2014) Biodegradation of polyethylene by Bacillus cereus. Adv Polym Sci Technol Int J 4(2):28-32. https://doi.org/10.1016/j.protcy.2016.05.031

Sun J, Dai X, Wang Q, van Loosdrecht MC, Ni B-J (2019) Microplastics in wastewater treatment plants: detection, occurrence and removal. Water Res 152:21-37. https://doi.org/10.1016/j.watre s.2018.12.050

Sundbæk KB, Koch IDW, Villaro CG, Rasmussen NS, Holdt SL, Hartmann NB (2018) Sorption of fluorescent polystyrene microplastic particles to edible seaweed Fucus vesiculosus. J Appl Phycol 30(5):2923-2927. https://doi.org/10.1007/s10811-018-1472-8

Sussarellu R, Suquet M, Thomas Y, Lambert C, Fabioux C, Pernet MEJ, Le Goïc N, Quillien V, Mingant C, Epelboin Y (2016) Oyster reproduction is affected by exposure to polystyrene microplastics. Proc Natl Acad Sci 113(9):2430-2435. https:// doi.org/10.1073/pnas.1519019113

Talsness CE, Andrade AJ, Kuriyama SN, Taylor JA, Vom Saal FS (2009) Components of plastic: experimental studies in animals and relevance for human health. Philos Trans R Soc B Biol Sci 364(1526):2079-2096. https://doi.org/10.1098/rstb.2008.0281

Talvitie J, Mikola A, Koistinen A, Setälä O (2017a) Solutions to microplastic pollution-removal of microplastics from wastewater effluent with advanced wastewater treatment technologies. Water Res 123:401-407. https://doi.org/10.1016/j.watres.2017.07.005

Talvitie J, Mikola A, Setälä O, Heinonen M, Koistinen A (2017b) How well is microlitter purified from wastewater? A detailed study on the stepwise removal of microlitter in a tertiary level wastewater treatment plant. Water Res 109:164-172. https://doi. org/10.1016/j.watres.2016.11.046

Ter Halle A, Ladirat L, Gendre X, Goudounèche D, Pusineri C, Routaboul C, Tenailleau C, Duployer B, Perez E (2016) Understanding the fragmentation pattern of marine plastic debris. Environ Sci Technol 50(11):5668-5675. https://doi.org/10.1021/acs. est.6b00594

Thompson RC (2015) Microplastics in the marine environment: sources, consequences and solutions. In: Marine anthropogenic litter. Springer, Cham, pp 185-200. https://doi.org/10.1007/9783-319-16510-3_7

Thompson RC, Olsen Y, Mitchell RP, Davis A, Rowland SJ, John AW, McGonigle D, Russell AE (2004) Lost at sea: where is all the plastic? Science 304(5672):838. https://doi.org/10.1126/scien ce. 1094559

Thompson RC, Moore CJ, Vom Saal FS, Swan SH (2009) Plastics, the environment and human health: current consensus and future trends. Philos Trans R Soc B Biol Sci 364(1526):2153-2166. https://doi.org/10.1098/rstb.2009.0053

Tofa TS, Kunjali KL, Paul S, Dutta J (2019) Visible light photocatalytic degradation of microplastic residues with zinc oxide nanorods. Environ Chem Lett. https://doi.org/10.1007/s10311-019-00859-z

Urbanek AK, Rymowicz W, Mirończuk AM (2018) Degradation of plastics and plastic-degrading bacteria in cold marine habitats.
Appl Microbiol Biotechnol 102(18):7669-7678. https://doi. org/10.1007/s00253-018-9195-y

Van Cauwenberghe L, Vanreusel A, Mees J, Janssen CR (2013) Microplastic pollution in deep-sea sediments. Environ Pollut 182:495499. https://doi.org/10.1016/j.envpol.2013.08.013

Van Franeker JA, Blaize C, Danielsen J, Fairclough K, Gollan J, Guse N, Hansen P-L, Heubeck M, Jensen J-K, Le Guillou G (2011) Monitoring plastic ingestion by the northern fulmar Fulmarus glacialis in the North Sea. Environ Pollut 159(10):2609-2615. https://doi.org/10.1016/j.envpol.2011.06.008

Vasile C, Pascu M (2005) Practical guide to polyethylene. iSmithers Rapra Publishing, Shrewsbury. https://doi.org/10.4236/ ojm.2013.340207232

Verschoor AJ (2015) Towards a definition of microplastics: Considerations for the specification of physico-chemical properties. National Institute for Public Health and the Environment, Bilthoven, The Netherlands, p 6

Wang W, Ndungu AW, Li Z, Wang J (2017) Microplastics pollution in inland freshwaters of China: a case study in urban surface waters of Wuhan, China. Sci Total Environ 575:1369-1374. https://doi. org/10.1016/j.scitotenv.2016.09.213

Wang L, Käppler A, Fischer D, Simmchen J (2019) Photocatalytic $\mathrm{TiO}_{2}$ micromotors for removal of microplastics and suspended matter. ACS Appl Mater Interface 11(36):32937-32944. https:// doi.org/10.1021/acsami.9b06128

Ward M (2015) Marine microplastic removal tool. Google Patents

Wexler P, Gad SC (1998) Encyclopedia of toxicology. Academic Press, New Yok

Wright SL, Kelly FJ (2017) Plastic and human health: a micro issue? Environ Sci Technol 51(12):6634-6647. https://doi.org/10.1021/ acs.est.7b00423

Yang L, Li K, Cui S, Kang Y, An L, Lei K (2019) Removal of microplastics in municipal sewage from China's largest water reclamation plant. Water Res 155:175-181. https://doi.org/10.1016/j. watres.2019.02.046

Yousif E, Haddad R (2013) Photodegradation and photostabilization of polymers, especially polystyrene. SpringerPlus 2(1):398-421. https://doi.org/10.1186/2193-1801-2-398

Zhang C, Chen X, Wang J, Tan L (2017) Toxic effects of microplastic on marine microalgae Skeletonema costatum: interactions between microplastic and algae. Environ Pollut 220:1282-1288. https://doi.org/10.1016/j.envpol.2016.11.005

Zhang K, Shi H, Peng J, Wang Y, Xiong X, Wu C, Lam PK (2018) Microplastic pollution in China's inland water systems: a review of findings, methods, characteristics, effects, and management. Sci Total Environ 630:1641-1653. https://doi.org/10.1016/j.scito tenv.2018.02.300

Zubris KAV, Richards BK (2005) Synthetic fibers as an indicator of land application of sludge. Environ Pollut 138(2):201-211. https ://doi.org/10.1016/j.envpol.2005.04.013 